\title{
Clinical Application for Screening Down's Syndrome by Using Carboxylated Graphene Oxide-Based Surface Plasmon Resonance Aptasensors
}

This article was published in the following Dove Press journal:

International Journal of Nanomedicine

\author{
Nan-Fu Chiu (iD) ${ }^{1,2}$ \\ Ying-Hao Wang ${ }^{1,3}$ \\ Chen-Yu Chen $\mathbb{1}^{3,4}$ \\ 'Laboratory of Nano-Photonics and \\ Biosensors, Institute of Electro-Optical \\ Engineering, National Taiwan Normal \\ University, Taipei City II677, Taiwan; \\ ${ }^{2}$ Department of Life Science, National \\ Taiwan Normal University, Taipei City \\ I 1677, Taiwan; ${ }^{3}$ Department of \\ Obstetrics and Gynecology, Mackay \\ Memorial Hospital, Taipei City 10449 \\ Taiwan; ${ }^{4}$ Department of Medicine, \\ Mackay Medical College, Taipei City \\ 25245, Taiwan
}

Background: Advanced medical detection technology requires high sensitivity and accuracy to increase the disease detection rate. We showed that carboxyl-functionalized graphene oxide (carboxyl-GO) biosensing materials are capable of accurate detection.

Methods: We developed a carboxylated GO-based surface plasmon resonance (SPR) aptasensor suitable for screening Down's syndrome in clinical serum. This biosensing material could rapidly and accurately detect hCG protein with a low concentration to identify fetal Down's syndrome. The developed carboxyl-GO-based SPR aptasensor showed excellent sensitivity and limit of detection without the use of antibodies and without any specific preference.

Results: hCG protein detection limits of $1 \mathrm{pM}$ in buffer samples and $1.9 \mathrm{pM}$ in clinical serum samples were achieved. The results showed that the carboxyl-GO-based chip could detect hCG well below the normal physiological level of serum protein $(5.0 \mathrm{mIU} / \mathrm{mL})$. High affinity, sensitivity, and better detection limit were obtained in the range of $1.9 \mathrm{pM}$ to 135 pM. The results showed a $5 \mathrm{k}$-fold dilution factor, and that an SPR angle shift of more than 20 millidegrees $\left(\mathrm{m}^{\circ}\right)$ was associated with a significant risk of fetal Down's syndrome compared to normal pregnant women. The results clearly showed that the detection of hCG protein in serum samples from pregnant women at 12-19 weeks could be used to screen Down's syndrome with high selectivity and sensitivity.

Conclusion: Our findings suggest the potential application of carboxyl-GO film in proof-ofconcept studies for serum assays as a new type of SPR material. In addition, peptide and carboxyl-GO films may be conducive to the development of future point of care testing and rapid diagnostic devices for other diseases such as cancer.

Keywords: surface plasmon resonance, SPR, aptasensor, carboxyl-functionalized graphene oxide, GO-COOH, peptides, human chorionic gonadotropin, hCG, Down's syndrome, DS

\section{Introduction}

Peptide aptamers are biological oligomers and include composites of nucleic acids, oligosaccharides and polysaccharides. They are hydrolyzed products obtained by hydrolyzing proteins through the action of enzymes. ${ }^{1,2}$ These chain molecules are formed by the dehydrative condensation of amine groups $\left(-\mathrm{NH}_{2}\right)$ and carboxyl groups $(-\mathrm{COOH})$ of amino acids to form peptide bonds that can selectively bind to specific sites on their target molecules. In the early 1980s, growth factors isolated

Chen-Yu Chen

Department of Obstetrics and Gynecology, Mackay Memorial Hospital, No. 92, Sec. 2, Zhongshan N. Road, Taipei City 10449, Taiwan

Tel +886-2-25433535

Fax +886-2-25433642

Email fl2248I@mmh.org.tw 
from human plasma were identified as being fragments of protein called peptides. ${ }^{3}$ Peptides have high thermal stability, high yield, good biocompatibility, tunable bioactivity, and a low-cost of production, ${ }^{4}$ and the self-assembly of peptides has unique advantages in the preparation of functional nanomaterials. In addition, peptides can be used to develop molecular electronic devices, ${ }^{5,6}$ and their adsorption properties for ions and organic molecules have tremendous potential for the application in tissue engineering, biosensors and related biomedical applications. ${ }^{7,8}$ In recent years, studies on synthetic receptors such as peptide aptamers and oligonucleotide aptamers have led to their use in replacing antibodies in biosensor applications, and they have been shown to have high affinity and high sensitivity as novel sensing probes. ${ }^{7,9-11}$ Among them, peptide aptamers have been used to develop successful new technologies for cross-field integration. For example, the integration of peptide aptamers and graphene oxide (GO) sheets has been used in memory devices, ${ }^{12}$ peptide aptamer-based bioactive regeneration scaffolds, ${ }^{13}$ and peptide aptamer-based biomimetic nanofiber hybrid hydrogels. ${ }^{14,15}$ Moreover, peptide aptamers can be used to enhance photocatalytic activity reactions, ${ }^{16}$ and in peptide aptamer-based fluorescence sensors ${ }^{17,18}$ and ultrasensitive label-free peptide aptamer-based protein detection applications. ${ }^{19-21}$

Recent advances in graphene-based surface plasmon resonance (SPR) biosensors for use in point-of-care diagnostics and new healthcare technologies have received increasing attention. ${ }^{22-34}$ These graphene-based SPR sensing technologies have been shown to be of particular importance in the detection of gynecological diseases, ${ }^{21,23,24}$ cancer, ${ }^{25,26}$ viruses, ${ }^{27,28}$ microbes, ${ }^{29,30}$ metal ions, ${ }^{31,32}$ and toxic substances. ${ }^{33,34}$ Human chorionic gonadotropin (hCG) has been shown to be an important biomarker for the detection of pregnancy and pregnancy-related disorders, as well as a useful tumor marker. ${ }^{35,36}$ hCG is an endocrine regulator and a hormone produced by the placenta after implantation. It is an important human hormone and a glycoprotein secreted by placental trophoblast cells during pregnancy. hCG has a molecular mass of $37.9 \mathrm{kDa}$ and a half-life of 24 to 36 hours until pre-pregnancy levels are reached. It is comprised of two subunits: a common alpha $(\alpha)$-subunit $(14.9 \mathrm{kDa})$, and a hormone beta $(\beta)$-subunit $(23 \mathrm{kDa}) .{ }^{37}$ Measuring the serum concentration of hCG is commonly used as an early detector of pregnancy, ${ }^{38}$ and it can also be used to diagnose ectopic pregnancies, ${ }^{39}$ miscarriage, ${ }^{40}$ testicular cancer, ${ }^{41}$ and ovarian tumors. ${ }^{42}$ For example, the normal range of hCG in the blood is $<5.0 \mathrm{mIU} / \mathrm{mL}$ (or $0.5 \mathrm{ng} / \mathrm{mL}$ or $13.2 \mathrm{pM}$ ), and concentrations above this threshold can be used as a positive test for testicular cancer. A blood test with an hCG concentration $<5.0$ $\mathrm{mIU} / \mathrm{mL}$ is considered to be negative for pregnancy, and anything $>25 \mathrm{mIU} / \mathrm{mL}$ is considered to be positive for pregnancy. ${ }^{43}$ In addition, a level of hCG in urine $<20$ $\mathrm{mIU} / \mathrm{mL}$ is also is considered to be negative for pregnancy. ${ }^{44,45}$ In general, the blood hCG level reaches a peak in the 12th week of pregnancy at about $288 \mathrm{IU} / \mathrm{mL}$ $(28.8 \mu \mathrm{g} / \mathrm{mL})$, and then declines and levels off for the remainder of the pregnancy. ${ }^{46}$

As hCG can be used to assess early pregnancy viability, fetal abnormalities and pregnancy-related diseases, its use as a biomarker has attracted widespread attention, and various new detection technologies have been developed. Among them, the technique of detecting hCG using a novel biosensor based on peptide aptamers has been successfully developed..$^{10,21,23,24,47-49}$ We previously reported a GO-based SPR biosensor to assay hCG in phosphate buffered saline (PBS) buffer that had a detection limit of $0.065 \mathrm{nM}^{21}$ In addition, we demonstrated that a GO-COOH-based SPR biosensor to assay hCG in the blood serum of pregnant women (14 weeks) had a detection limit of $1.15 \mathrm{pM}\left(\theta_{\mathrm{SPR}}=1.56 \pm\right.$ $\left.0.2 \mathrm{~m}^{\mathrm{o}}\right) .{ }^{24}$ We also successfully demonstrated that the SPR angle responses of immobilized peptides and carboxyl-GO surfaces at high flow rate were not conducive to the immobilization of peptides on a carboxyl-GO surface. Our previous work showed that GO-based ${ }^{21,50}$ and GO-COOH-based ${ }^{24,51,52}$ sensing films can improve the sensitivity of detection.

In this paper, we developed a novel SPR aptasensor that was fabricated by combining the bio-affinity of carboxyl-GO sheets and the excellent specificity of peptide aptamers. We successfully demonstrated that carboxyl-GO -based SPR aptasensors can be used to analyze serum samples from women with fetal Down's syndrome (DS) with high sensitivity and high precision. This is the first time that this technique has been used in clinical experiments to screen women with fetal DS through hCG protein diagnostic analysis. The fetal DS screening values showed statistically significant differences. Furthermore, this peptide-carboxyl-GO film had excellent strong binding properties requiring a smaller sample volume and thereby significantly lowering the concentration required for the 
SPR aptasensor assay. More significantly, it could appreciably reduce the non-specific adsorption of molecules.

This is because the two ends of a peptide usually have two functional groups: an amino end and a carboxyl end. The N-terminus of each peptide chain (the amine groups $\left(-\mathrm{NH}_{2}\right)$ ) facilitated a strong reaction with the exposed high density of carboxyl-groups available on the surface of the carboxyl-GO sheet. This enabled the highly sensitive identification of hCG with peptide-carboxyl-GO sensing films through highly specific binding reactions, highlighting their potential use in clinical diagnostic chips. This carboxyl-GO binding peptide technique may provide an alternative to antibody-based biosensors, and this sensing technology may be applied to SPR aptasensors and show potential in early pregnancy testing or cancer diagnosis.

\section{Materials and Methods Materials}

Single atomic layer GO sheet solution (Graphene Laboratories Inc., USA) at $60 \% \sim 70 \%$ and a carbon/oxygen ratio of $4: 1$ were used, with a flake size $<1 \mu \mathrm{m}$ and thickness of approximately $1.1 \mathrm{~nm}$ by ultrasonic exfoliation. The linkers cystamine dihydrochloride (Cys, $\mathrm{SH}-\mathrm{NH}_{2}, 97 \%$, Alfa Aesar Co., Ward Hill, MA, USA), chloroacetic acid (Cl- $\mathrm{CH}_{2}-\mathrm{COOH}, 99 \%$ ), and $\mathrm{N}$-hydroxysuccinimide (NHS) were purchased from Alfa Aesar Co. (USA). Other reagents including 1-ethyl-3-(3-dimethylaminopropyl)carbodiimide (EDC), ethanolamine (EA), sodium hydroxide $(\mathrm{NaOH})$, bovine serum albumin (BSA), and hCG protein were purchased from Sigma-Aldrich Inc. (USA). Recombinant hCG was expressed in a mouse cell line and had an apparent molecular weight of $>50 \mathrm{kDa}$ (Recombinant hCG, product number: 1297001, Sigma-Aldrich, USA). The peptide aptamer was a short oligopeptide sequence ${ }^{10} \quad \mathrm{NH}_{2}$ PPLRINRHILTR-COOH (N-Pro-ProLeu-Arg-Ile-Asn-Arg -His-Ile-Leu-Thr-Arg-C) and was synthesized by Purigo Biotechnology Co., Ltd. (Taiwan).

For the clinical specimens, we used serum samples from women with normal pregnancy $(n=4)$ and from women with fetal DS $(\mathrm{n}=6)$ collected from Mackay Memorial Hospital (Taipei, Taiwan). The hCG concentration in all serum samples was measured by enzymelinked immunosorbent assay (ELISA, spectra max 190, Molecular Devices, LLC., CA, USA). These serum samples were obtained during 12-19 weeks of pregnancy.

\section{Preparation of Carboxyl-GO-Peptide Based on a Non-Immune SPR Aptasensor and hCG Detection Method in PBS Buffer}

Chloroacetic acid was used as an alkylating agent to modify the carboxyl-GO sensing films as previously described. ${ }^{51-54}$ Carboxyl-GO sheets were immobilized on the sensing substrate that was a 47-nm thick gold ( $\mathrm{Au}$ ) film to form sensing films as shown in Figure 1. We used Cys at a concentration of $5 \mathrm{mM}$ in a volume of $1 \mathrm{~mL}$ to generate thiol selfassembled monolayers (SAMs) on bare Au film surfaces for 24 hours as shown in Figure 1A and B. Carboxyl-GO sheets at a concentration of $1 \mathrm{mg} / \mathrm{mL}$ in a volume of $0.5 \mathrm{~mL}$ were immobilized as a carboxyl-GO sensing layer on the $\mathrm{Au}$ film for 5 hours as shown in Figure 1B and C. This carboxyl-GO sensing layer and Cys formed a covalent bond by chemical reactions with $-\mathrm{COOH}$ and $\mathrm{NH}_{2}$. Figure $1 \mathrm{C}$ and $\mathrm{D}$ show the activation process of $-\mathrm{COOH}$ functional groups on the surface of the carboxyl-GO sheets. This activator was mixed with EDC and NHS in a volume ratio of $1: 1$ and concentrations of $0.4 \mathrm{M}$ and $0.1 \mathrm{M}$, respectively.

To detect hCG protein in the PBS buffer study, we used the static immobilization method to titrate $1 \mathrm{~mL}$ of the peptide at a concentration of $100 \mu \mathrm{M}$ on a carboxy-GO chip and stored it in a refrigerator for 5 hours. Figure 1E shows the immobilization of the peptide probes at a concentration of $100 \mu \mathrm{M}$. We used carboxyl-GO by activating the $-\mathrm{COOH}$ end for peptide-amine reactions to form a strong chemical covalent bond. We previously found that an increased peptide immobilization time can enhance detection sensitivity. ${ }^{24}$ This method (static immobilization method) increased the immobilization time so as to achieve a high density of peptides immobilized on the carboxyl-GO sensor to increase sensitivity.

The carboxyl-GO-based SPR aptasensor had affinity for the highly specific binding between hCG proteins. The carboxyl-GO binding peptide probe was used in the hCG protein assay experiments as shown in Figure 1F. EA at a high concentration $(1 \mathrm{M})$ was used to block unreacted linker, and $\mathrm{NaOH}$ solution $(50 \mathrm{mM})$ at a $\mathrm{pH}$ of 12 was used to regenerate the hCG protein shedding dissociation reaction. In this study, hCG protein was diluted using PBS buffer (1X, pH 7.4), and the running buffer was used in PBS buffer.

As mentioned above, although not all of the samples used the same chip, we calibrated each chip according to the SPR microfluidic channel on a BI-SPR 3000 dual channel instrument (Biosensing Instrument Inc., Tempe, 


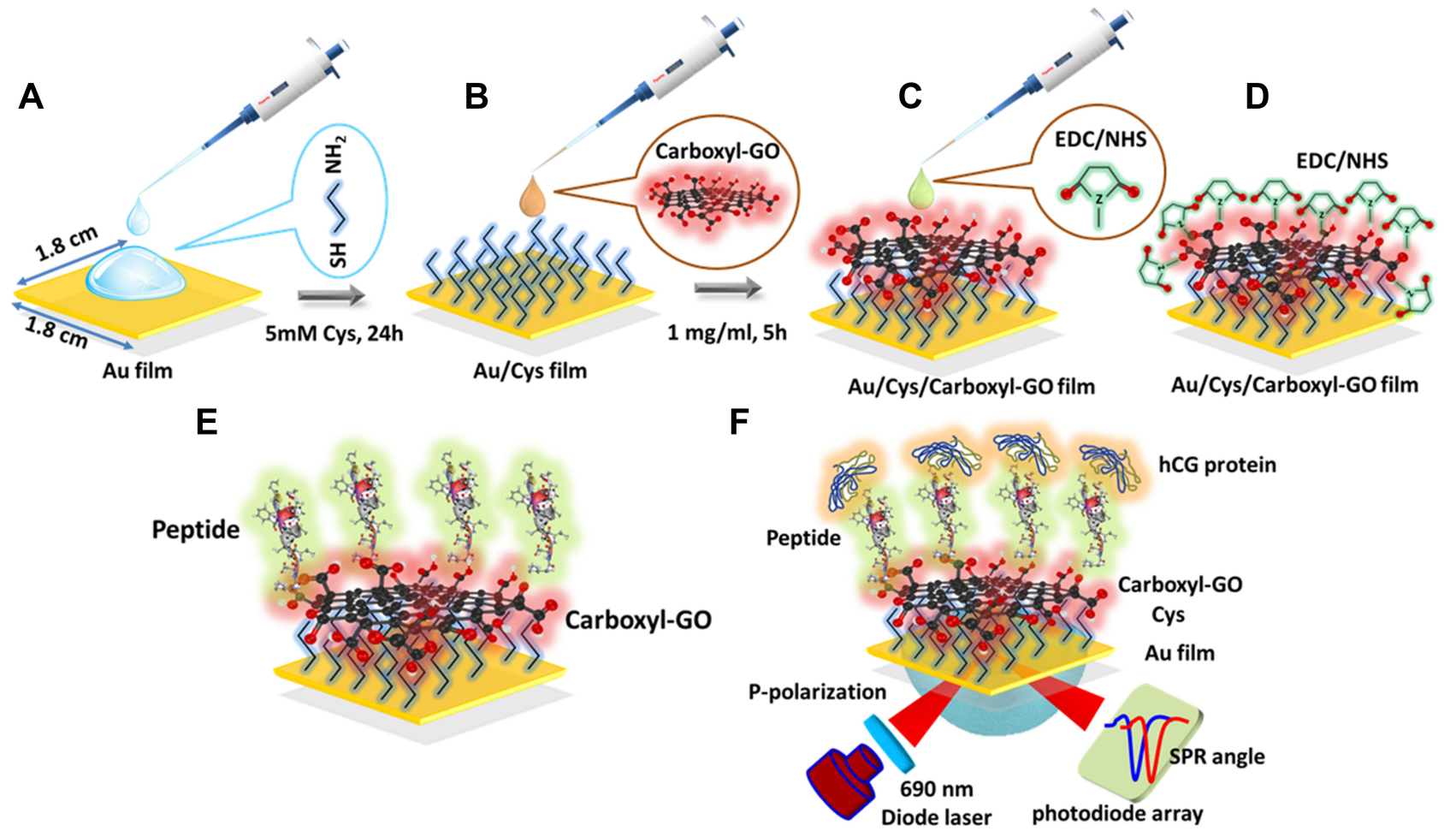

Figure I A schematic diagram of chemical coupling to carboxyl-GO sheets and peptide probe immobilization on the surfaces of SPR aptasensors to produce a thiol-reactive coupling surface. (A) The self-assembled monolayer linker of a bare Au surface via Cys thiol-Au interactions. (B) The carboxyl-GO sheets were immobilized on the Au surface via $\mathrm{NH}_{2}-\mathrm{COOH}$ interactions. (C) EDC/NHS was used to activate the $-\mathrm{COOH}$ functional groups. (D) The EDC/NHS that activated the carboxyl-GO films was covalently attached to the amine group of $\mathrm{Cys}$. Ethylenediamine was used to block unreacted linkers, and the amino group of peptide was covalently attached to - $\mathrm{COOH}$ of GO. (E) Monoclonal peptides were immobilized on carboxyl-GO surfaces via $\mathrm{NH}_{2}-\mathrm{COOH}$ interactions. (F) The interaction between the hCG analyte and biorecognition peptide created a signaling event SPR angle shift by the interfaced carboxyl-GO film.

Abbreviations: Carboxyl-GO, carboxyl-graphene oxide; SPR, surface plasmon resonance; SAM, self-assembled monolayer; Au, gold; Cys, cystamine; $\mathrm{NH}_{2}$, amine groups; EDC/NHS, I-ethyl-3-(3-dimethylaminopropyl)carbodiimide/N-hydroxysuccinimide; COOH, carboxyl groups; hCG, human chorionic gonadotropin.

AZ, USA) calibration rule. This was the standard procedure before the experiment, so that the SPR angle of each chip had the same baseline.

\section{Preparation of Carboxyl-GO-Peptide Based on a Non-Immune SPR Aptasensor and hCG Detection Method in Serum}

\section{Samples}

In the clinical serum samples study, hCG was assayed in order to further evaluate interactions between the peptide and hCG protein in kinetic analysis and the limit of detection (LOD). We immobilized the peptide probe according to the SPR microfluidic channel (dynamic immobilization method). We used a flow rate of $30 \mu \mathrm{L} / \mathrm{min}$, as this has been shown to be beneficial when observing the binding and immobilization reactions of peptides and carboxyl-GO surfaces. Subsequent injections with $1 \mathrm{X}$ PBS buffer cleared the unbound peptides, followed by blocking of the unbound linker with a high concentration of $1 \mathrm{mg} / \mathrm{mL}$ BSA protein.
Finally, $50 \mathrm{mM}$ of $\mathrm{NaOH}$ was used to eliminate all noncovalent and non-specific binding molecules. The dynamic method of activation and all peptide immobilization procedures were performed in a volume of $200 \mu \mathrm{L}$ and a flow rate of $30 \mu \mathrm{L} / \mathrm{min}$ into the BI-SPR system to detect hCG protein. The running buffer was composed of $0.05 \%$ Tween-20 (P9416, Sigma-Aldrich, USA), and BSA protein mixed at a concentration of $1 \mathrm{mg} / \mathrm{mL}$ in a volume of $600 \mu \mathrm{L}$ in $100 \mathrm{~cm}^{3}$ of $1 \mathrm{x}$ PBS to prevent non-specific binding of proteins to the carboxyl-GO surface in the human serum specimens. To detect hCG in the clinical serum samples, we used a running buffer spiked with different dilutions of serum samples, at dilution factors of $5 \mathrm{k}$ (diluted $5 \mathrm{k}: 1$ with buffer), $10 \mathrm{k}, 25 \mathrm{k}, 50 \mathrm{k}, 100 \mathrm{k}, 200 \mathrm{k}$ in a total volume of $200 \mu \mathrm{L}$.

\section{Preparation Procedure of Evaluated Selectivity Tests}

To detect hCG protein in the selectivity experiments, we used five different non-specific proteins including BSA 
( $\geq 99 \%$, product number: A0281, Sigma-Aldrich), human serum albumin (HSA, $\geq 98 \%$, product number: SRP618, Sigma-Aldrich, USA), pregnancy-associated plasma protein A (PAPP-A, product number: MBS2011936, MyBiosource, Inc. USA), pregnancy-associated plasma protein A2 (PAPP-A2, product number: MBS2011332, MyBiosource, Inc. USA), and human cytokeratin 19 (CK-19, product number: NBP2-23164, Novus Biologicals, USA). In addition, we used the different proteins (BSA, HSA, PAPP-A, PAPP-A2, CK-19, and hCG) at a concentration of $500 \mathrm{pM}$ each and a volume of $200 \mu \mathrm{L}$ in PBS buffer and in spiked 10\% serum buffer, respectively. All hCG protein assay experiments were conducted at room temperature $\left(23 \pm 0.5^{\circ} \mathrm{C}\right)$, using a sample injection volume of $200 \mu \mathrm{L}$ and a flow rate of $30 \mu \mathrm{L} / \mathrm{min}$.

\section{Results and Discussion \\ Analysis of the Surface Morphology of Carboxyl-GO Films}

Figure 2A shows a scanning electron microscope (SEM, JEOL Inc., USA) photograph of fabricated carboxyl-GO films on $\mathrm{Au}$ chip substrates with the structural features of the surface. Transmission electron microscope (TEM; Tecnai G2F30S-Twin, Philips-FEI, Amsterdam, Netherlands) images of fabricated carboxyl-GO films revealed them to be of a layer-by-layer lamination and organic shell matrix structure as shown in Figure 2B. This phenomenon was caused by carboxylic acid, so that the carboxyl-GO surface became an organic chitosan matrix with a hydrophilic functional group. ${ }^{51,52,54}$ Figure $2 \mathrm{C}$ shows an atomic force microscope (AFM) photograph of these fabricated carboxyl-GO
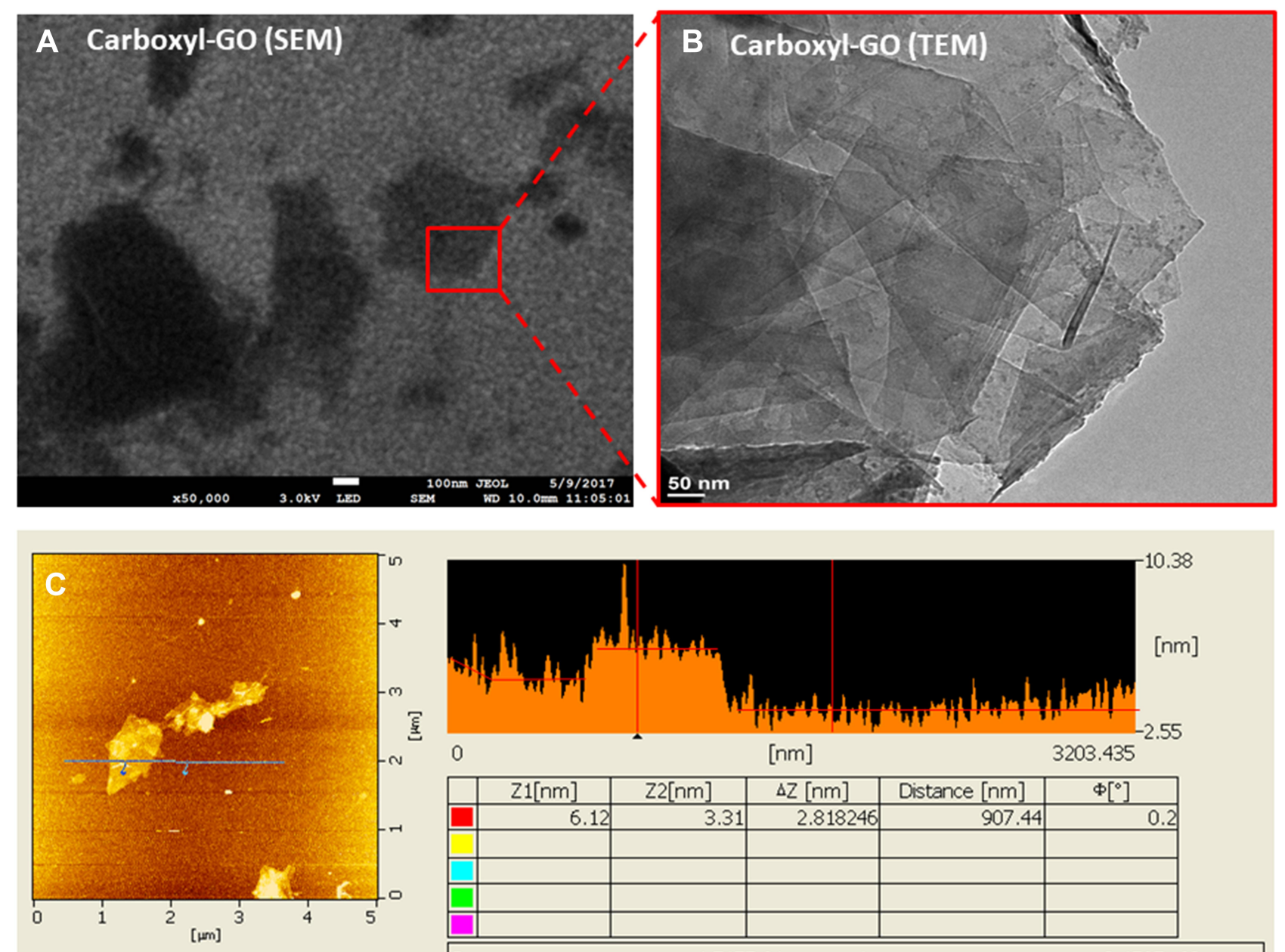

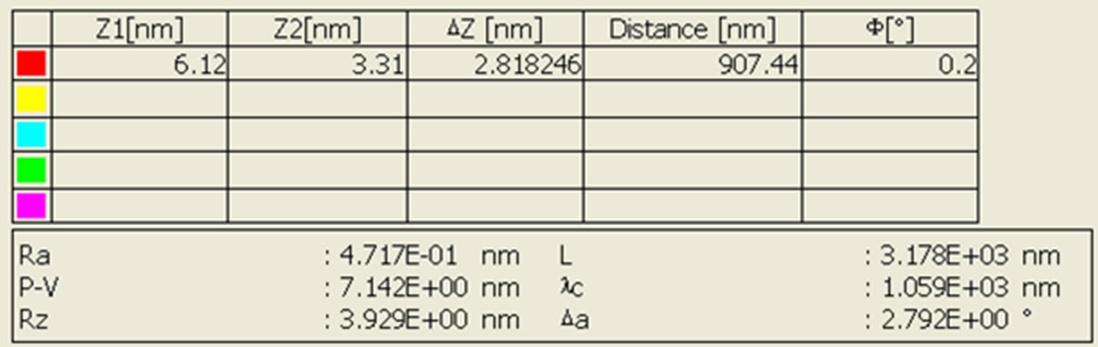

Figure 2 Photograph and profile of synthesized carboxyl-GO films for (A) SEM (B) TEM, and (C) AFM images.

Abbreviations: Carboxyl-GO, carboxyl-graphene oxide; SEM, scanning electron microscope; TEM, Transmission electron microscope; AFM, atomic force microscope. 
films and height profile of the synthesized carboxyl-GO films. The thickness of the synthesized carboxyl-GO films was calculated to be $2.8 \mathrm{~nm}$ according to the height profile diagram of the AFM image.

\section{Analysis of the Zeta Potential, Fourier Transform Infrared Spectroscopy, and $X$-Ray Photoelectron Spectroscopy of Carboxyl-GO Sheets}

To examine the physical properties of the carboxyl-GO sheets, we analyzed the zeta potential (ZP) measurements (Nano ZS, Malvern Panalytical Ltd., United Kingdom) in aqueous suspension solutions of GO and carboxyl-GO of the surface charge of the sheets as shown in Figure 3A. With regards to the carboxyl-GO sheet properties of the charged particles, the magnitude of ZP describes the degree of electrostatic repulsion between charged particles in a dispersed solution. A particle potential $<30 \mathrm{mV}$ shows the unstable behavior of a dispersed solution and the occurrence of aggregation. This phenomenon indicates that the repulsive force between particles is much higher than the attraction. ${ }^{55}$ In Figure $3 \mathrm{~A}$, the results showed that the $\mathrm{ZP}$ value was $-35.7 \mathrm{mV}(\mathrm{pH} 5.0)$ for $\mathrm{GO}$ and -34.4 $\mathrm{mV}(\mathrm{pH}$ 3.6) for carboxyl-GO, a measure of the stability of the particles with no particle agglomeration. The negative ZP value was attributed to the characteristics caused by the presence of oxygen functional species on the GO surface. $^{56}$

Figure 3B shows that the $\mathrm{ZP}$ of aqueous suspensions of carboxyl-GO sheets as a function of $\mathrm{pH}$ was important to determine the surface charge of the carboxyl-GO sheets. We used different $\mathrm{pH}$ conditions for the ZP measurements, which were done to evaluate the dispersibility and stability of the carboxyl-GO sheets on the chips. This showed the uniformity of the thickness of the sensing film, which was conducive to the immobilization and self-assembly of carboxyl-GO sheets on the chip surfaces. The results showed that the carboxyl-GO sheets were highly negatively charged with a value from -29.7 to $-46.3 \mathrm{mV}$ at a $\mathrm{pH}$ ranging between 3 and 10. In addition, the $\mathrm{ZP}$ versus $\mathrm{pH}$ measured for the carboxyl-GO sheets in aqueous suspensions at linear regression equations of the calibration curves was $y=-25.29-2.19 x$ with a correlation coefficient $R^{2}$ of 0.94 . The measured ZPs showed the suitability of fixing the negatively charged carboxyl-GO sheets on the surface of the chips because of their good dispersibility. In addition, negatively charged carboxyl-GO sheets could improve electron transfer on the surface.

Figure $3 \mathrm{C}$ shows the Fourier transform infrared spectroscopy spectra of GO and carboxyl-GO sheets. The spectrum of carboxyl-GO showed the presence of bands associated with epoxide groups $\left(\mathrm{C}-\mathrm{O}-\mathrm{C}, 910 \mathrm{~cm}^{-1}\right)$, hydroxyl groups $\left(\mathrm{C}-\mathrm{OH}, 1064 \mathrm{~cm}^{-1}\right), \mathrm{C}-\mathrm{OH}$ groups $\left(1455 \mathrm{~cm}^{-1}\right)$, carboxylic acid $\left(-\mathrm{COOH}, 1663 \mathrm{~cm}^{-1}\right)$ and carbonyl $\left(\mathrm{C}=\mathrm{O}, 1734 \mathrm{~cm}^{-1}\right)$ moieties that were present mostly along sheet edges but also on the basal plane of the graphene sheets, and a broad peak between 3000 and $3800 \mathrm{~cm}^{-1}$ corresponding to $-\mathrm{OH}$ vibration $\left(3325 \mathrm{~cm}^{-1}\right)$. Although GO and GO-COOH have similar chemical bond vibration characteristic peaks, the results showed that the carboxyl-GO spectrum exhibited only two peaks at $1064 \mathrm{~cm}^{-1}(\mathrm{C}-\mathrm{OH})$ and $1663 \mathrm{~cm}^{-1}(\mathrm{COOH})$, and a reduced $-\mathrm{OH}$ peak at $3325 \mathrm{~cm}^{-1}$, suggesting that the carboxyl-GO had been effectively modified by the chloroacetic acid process. ${ }^{24,51,52}$

Figure 3D-F shows the presence of carbon and oxygen elemental and chemical state analyses in the GO and carboxyl-GO sheets using X-ray photoelectron spectroscopy (XPS).

Figure 3D shows a representative XPS survey spectrum of GO and carboxyl-GO sheets on Au film surface, which clearly demonstrated the existence of S2s, C1s, Au4d, N1s, and O1s. The results showed that the sulfur of S2s, carbon of C1s, gold of $A u 4 d_{5 / 2}$ and $A u 4 d_{3 / 2}$, nitrogen of N1s, and oxygen of O1s peaks were 238, 284.5, 335.5, 353.5, 400, and $532.5 \mathrm{eV}$ in the XPS survey spectra, respectively. Among them, the S2s peak was caused by the -SH of the Cys linker, and the N1s peak at $400 \mathrm{eV}$ was caused by immobilization of the Cys linker -NH bonding on the GO and carboxyl-GO surface. In addition, the relative intensity ratio of XPS carbon-to-oxygen peak $\left(\mathrm{I}_{\mathrm{C} 1 \mathrm{~s}} / \mathrm{I}_{\mathrm{O} 1 \mathrm{~s}}\right)$ increased from 0.94 for $\mathrm{GO}$ to 1.02 for carboxyl-GO sheets. The increase in carbon element in these experiments meant that the modification of $-\mathrm{COOH}$ had been successful. Multiplex high-resolution scans of $\mathrm{C} 1 \mathrm{~s}$ and O1s spectral regions of the carboxyl-GO sheets are shown in Figure 3E and F, respectively. Figure 3E demonstrates that the $\mathrm{C} 1 \mathrm{~s}$ peak could be best fitted by a combination of five C1s peaks of $\mathrm{sp}^{2}(\mathrm{C}=\mathrm{C}, 15.6 \%), \mathrm{sp}^{3}(\mathrm{C}-\mathrm{C}, 24.1 \%)$, epoxy (C-O, 26.9\%), carbonyl $(\mathrm{C}=\mathrm{O}, 28.3 \%)$, carboxyl (O-C $=\mathrm{O}, 5.1 \%$ ), which were observed at $284.15,284.65$, $285.2,286.8$, and $288.75 \mathrm{eV}$, respectively. Therefore, carboxyl-GO sheets with many - $\mathrm{COOH}$ groups had been modified effectively. The carboxyl peak at $288.75 \mathrm{eV}$ in the spectrum of $\mathrm{O}-\mathrm{C}=\mathrm{O}$ contents constituted $5.1 \%$ of the 

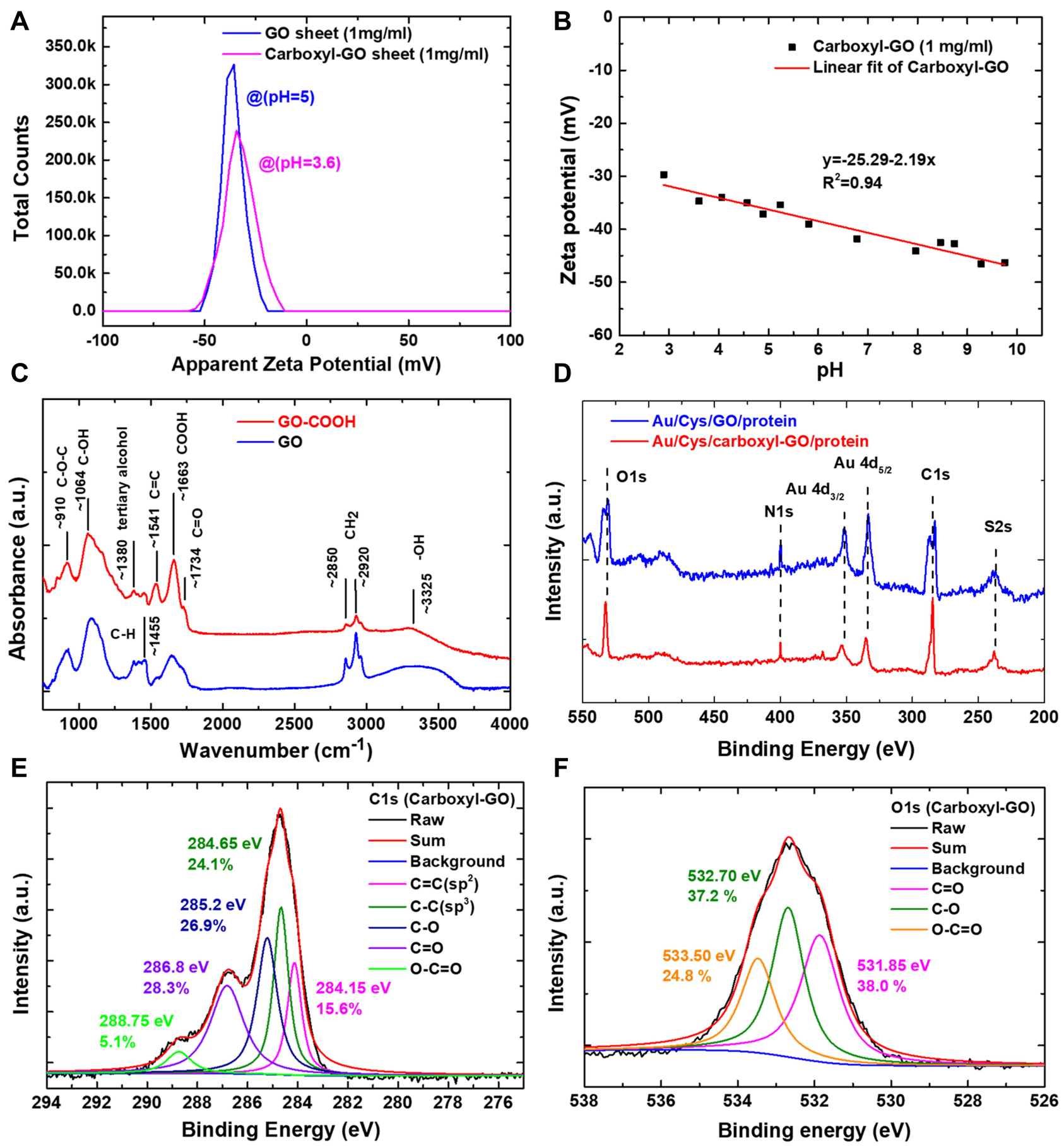

Figure 3 Electrical properties of fabricated carboxyl-GO sheets in solution and films. (A) Zeta potential distribution curve of GO and carboxyl-GO sheets in aqueous suspensions. (B) Zeta potential analysis at different pH values of carboxyl-GO sheets synthesized using chloroacetic acid. (C) FTIR curves of GO and carboxyl groupmodified GO. (D) Survey XPS spectrum of GO and carboxyl-GO sheets. High-resolution XPS scan spectra of the (E) Cls and (F) Ols regions of the carboxyl-GO sheets. Abbreviations: Carboxyl-GO, carboxyl-graphene oxide; GO, graphene oxide; FTIR, Fourier transform infrared spectroscopy; XPS, X-ray photoelectron spectroscopy.

carboxyl-GO sheets (generally, the $\mathrm{O}-\mathrm{C}=\mathrm{O}$ contents of $\mathrm{GO}$ are $<2 \%$ ). ${ }^{24,57-59}$ Figure $3 \mathrm{~F}$ shows that the $\mathrm{O} 1 \mathrm{~s}$ peak could be best fitted by a combination of three $\mathrm{O} 1 \mathrm{~s}$ peaks of $\mathrm{C}=\mathrm{O}$ (38.0\%), C-O (37.2\%), and $\mathrm{O}-\mathrm{C}=\mathrm{O} \quad(24.8 \%)$, which were observed at $531.85,532.70$ and $533.50 \mathrm{eV}$, respectively.
The O1s peak of high content $\mathrm{O}-\mathrm{C}=\mathrm{O}(24.8 \%)$ on the carboxyl-GO surface confirmed that most of the carboxylfunctionalization of GO sheets had been successful. These experimental results are consistent with previous studies. ${ }^{25,51}$ 


\section{Analysis of the Optical Properties of Carboxyl-GO-Based Sensing Structure}

Figure 4A shows the ultraviolet-visible (UV-Vis) absorbance spectra (U-2900, Hitachi High-Technologies Corporation, Japan) and optical band gaps of the GO and synthesized carboxyl-GO sheets as a function of wavelength. $\mathrm{GO}$ exhibited an absorption peak at $225 \mathrm{~nm}$ corresponding to the $\pi-\pi^{*}$ transition of $\mathrm{C}=\mathrm{C}$ bonds due to aromatic ring electrons, and a weak absorption band near $300 \mathrm{~nm}$ (small shoulder) attributable to $\mathrm{n}-\pi^{*}$ transitions of aromatic $\mathrm{C}-\mathrm{O}$ and $\mathrm{C}=\mathrm{O}$ bonds due to carbonyl group electrons. ${ }^{25,58}$ The absorption spectrum of carboxyl-GO samples demonstrated a characteristic absorption peak at $232 \mathrm{~nm}$ corresponding to the $\pi-\pi^{*}$ transition of $\mathrm{C}=\mathrm{C}$ bonds of the aromatic system. Compared to the GO sheets, the carboxyl-GO sheets had a 7-nm shift in the absorption peak at $232 \mathrm{~nm}$ attributed to a decrease in oxygen functional groups and increase in carboxyl groups causing the electrons to be easily excited at a lower energy. The optical band gaps from the behavior of absorption coefficient spectra of GO and carboxyl-GO sheets could be interpreted by calculating the existence of direct optical band gap transitions. Tauc's plot ${ }^{60,61}$ of $(\alpha h v)^{2}$ versus the energy gap $(\mathrm{eV})$ with a linear extrapolation is shown in Figure 4A. The Tauc optical band gap was determined by fitting the linear part of the curves of the incident radiation to intercept the energy axis (at $\alpha=0$ ). The linear dependence of Tauc's plot on hv indicated that the GO and
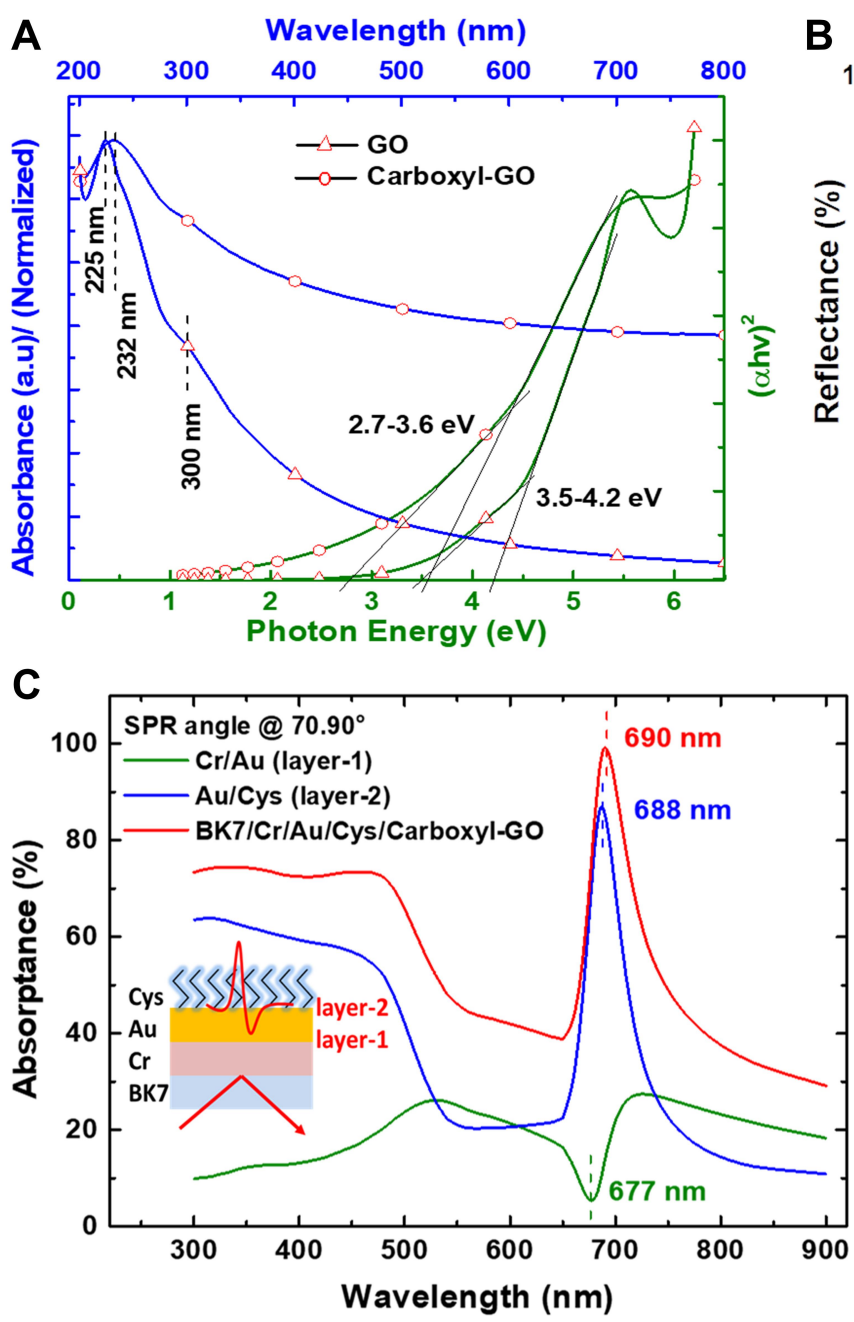
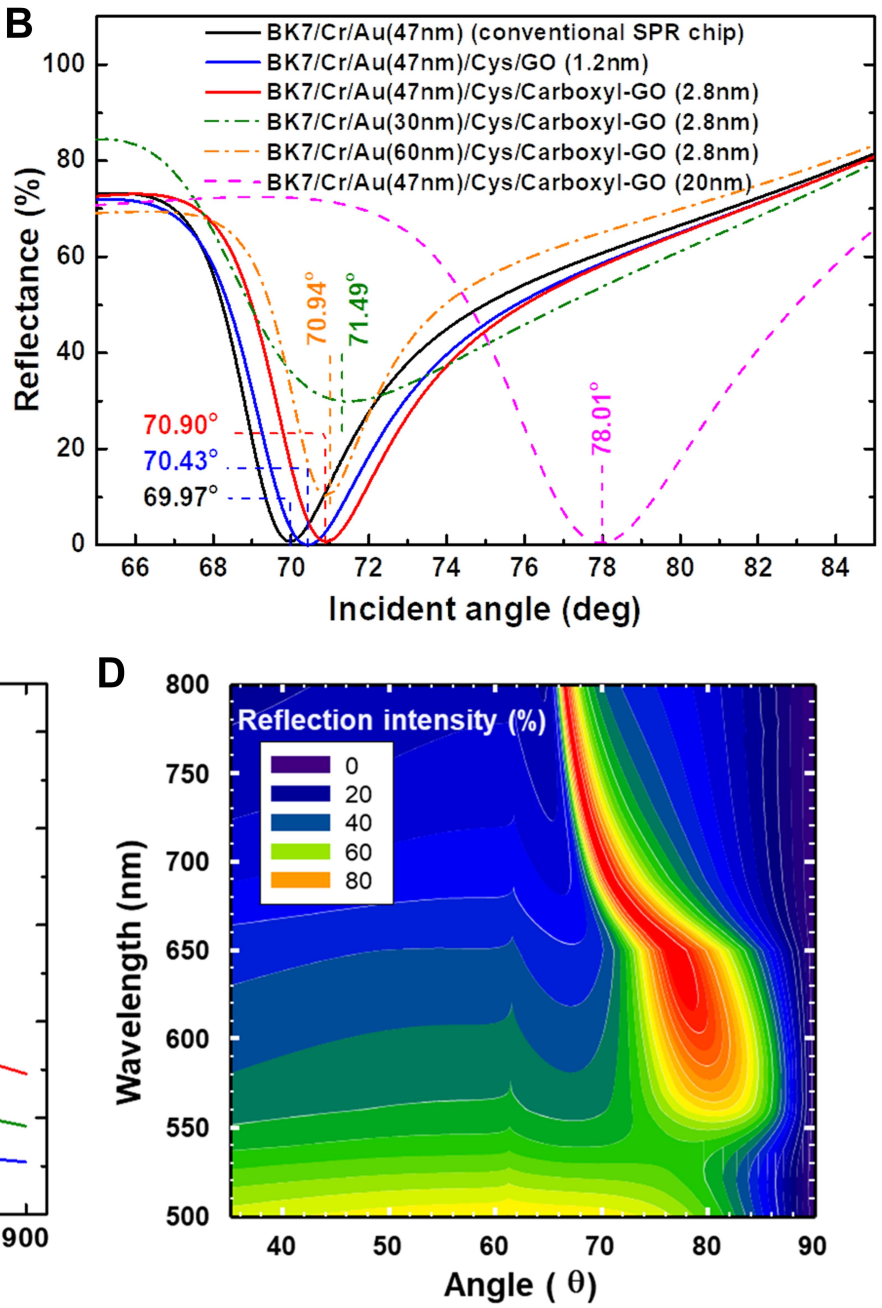

Figure 4 (A) Absorption spectra and band-gap of GO, carboxyl-GO dispersions in DI water. (B) SPR reflectance curve for the GO and carboxyl-GO sensing chips in comparison to the conventional Au chip. (C) Characterization of absorption properties at multilayer interface absorption spectra corresponding to Cr/Au, Au/Cys and BK7/ $\mathrm{Au} / \mathrm{Cr} / \mathrm{Cys} / \mathrm{carboxyl}-\mathrm{GO}$ in water. (D) Dispersion relationship of SP propagating along a flat modulation at the $\mathrm{BK} 7 / \mathrm{Au} / \mathrm{Cr} / \mathrm{Cys} / \mathrm{carboxyl}-\mathrm{GO}$ structure in contact with water at the interface.

Abbreviations: GO, graphene oxide; Carboxyl-GO, carboxyl-graphene oxide; DI water, Deionized water; SPR, surface plasmon resonance; Au, gold; Cr, chromium; Cys, cystamine. 
carboxyl-GO sheets showed an intrinsic semiconductorlike absorption in the blue optical region, and the band gap value was the value of the carboxyl-GO sheets for 2.7-3.6 $\mathrm{eV}$. The corresponding GO sheet band gap value was 3.5-4.2 eV.

Figure 4B shows the SPR reflectance curve at functions of incident angles of $65-85^{\circ}$ (internal angle) using Fresnel's law for a multilayer system to calculate the Kretschmann configuration. ${ }^{52,54,62}$ The $\mathrm{k}$ of GO and carboxyl-GO according to previous studies is 0 to calculate the resonance curve. ${ }^{25,52,59}$

We used the refractive index (n), extinction coefficient (k) and thickness (d) constants for layers of $0.16,3.817$ and $47 \mathrm{~nm}$ for $\mathrm{Au}, 3.798,4.368$ and $2 \mathrm{~nm}$ for $\mathrm{Cr}$, and 1.45, 0 and $0.5 \mathrm{~nm}$ for Cys, ${ }^{63} 1.706,0$ and $1.2 \mathrm{~nm}$ for GO, ${ }^{59}$ $1.673,0$ and $2.8 \mathrm{~nm}$ for carboxyl-GO to fit calculations of the SPR angle at a wavelength of $690 \mathrm{~nm}$. We analyzed the SPR multilayer system in BK7/Cr/Au (conventional SPR chip), BK7/Cr/Au/Cys/GO and BK7/Cr/Au/Cys/carboxylGO in a water interface environment. The SPR curves for the GO and carboxyl-GO chips were acquired in order to compare them with the SPR curve for the conventional $\mathrm{Au}$ chip.

The SPR angles for the $\mathrm{Bk} 7 / \mathrm{Cr} / \mathrm{Au}(47 \mathrm{~nm}), \mathrm{BK} 7 / \mathrm{Cr} / \mathrm{Au}$ $(47 \mathrm{~nm}) / \mathrm{Cys} / \mathrm{GO}(1.2 \mathrm{~nm})$ and $\mathrm{BK} 7 / \mathrm{Cr} / \mathrm{Au}(47 \mathrm{~nm}) / \mathrm{Cys} / \mathrm{car}-$ boxyl-GO $(2.8 \mathrm{~nm})$ chips were $69.97^{\circ}, 70.43^{\circ}$ and $70.90^{\circ}$, respectively. The full width at half maximum (FWHM) for the $\mathrm{Bk} 7 / \mathrm{Cr} / \mathrm{Au}(47 \mathrm{~nm}), \mathrm{BK} 7 / \mathrm{Cr} / \mathrm{Au}(47 \mathrm{~nm}) / \mathrm{Cys} / \mathrm{GO}(1.2 \mathrm{~nm})$ and $\mathrm{BK} 7 / \mathrm{Cr} / \mathrm{Au}(47 \mathrm{~nm}) / \mathrm{Cys} /$ carboxyl-GO(2.8nm) chips were $4.12^{\circ}, 4.66^{\circ}$ and $4.49^{\circ}$, respectively.

In order to further analyze the changes in SPR curves caused by different thicknesses, we evaluated the effect of different thicknesses on the performance of sensing.

We changed the design of the three chips with different thicknesses and analyzed the SPR angle shifts for the BK $7 / \mathrm{Cr} /$ $\mathrm{Au}(30 \mathrm{~nm}) / \mathrm{Cys} /$ carboxyl-GO(2.8nm), $\mathrm{BK} 7 / \mathrm{Cr} / \mathrm{Au}(60 \mathrm{~nm}) /$ Cys/carboxyl-GO(2.8nm), and $\mathrm{BK} 7 / \mathrm{Cr} / \mathrm{Au}(47 \mathrm{~nm}) / \mathrm{Cys} /$ carboxyl-GO(20nm), which were $71.49^{\circ}, 70.94^{\circ}$ and $78.01^{\circ}$, respectively. The results showed that the SPR angle had a large shift, which caused the FWHM to become larger and the coupling ratio to become smaller (higher reflectance).

The results of FWHM analysis for the $\mathrm{BK} 7 / \mathrm{Cr} / \mathrm{Au}$ (30nm)/Cys/carboxyl-GO(2.8nm), BK7/Cr/Au(60nm)/Cys/ carboxyl-GO $(2.8 \mathrm{~nm})$, and $\mathrm{BK} 7 / \mathrm{Cr} / \mathrm{Au}(47 \mathrm{~nm}) / \mathrm{Cys} /$ carboxyl-GO $(20 \mathrm{~nm})$ chips were $10.43^{\circ}, 3.02^{\circ}$, and $6.2^{\circ}$, respectively. From the calculation and analysis of these experiments, we found that reducing the thickness of the gold film from $47 \mathrm{~nm}$ to $30 \mathrm{~nm}$ resulted in a lower coupling ratio and a larger FWHM (from $4.49^{\circ}$ to $10.43^{\circ}$ ). A gold film thickness larger or smaller than $47 \mathrm{~nm}$ was not conducive to high-sensitivity sensing. In addition, increasing the thickness of carboxyl-GO from $2.8 \mathrm{~nm}$ to $20 \mathrm{~nm}$ led to excessive SPR angle displacement (from $70.90^{\circ}$ to $78.01^{\circ}$ ) and larger FWHM (from $4.49^{\circ}$ to $6.2^{\circ}$ ). These results showed that a too large SPR angle and FWHM caused the angular displacement in the sensing to become smaller, thereby decreasing the sensitivity. These experimental analyses showed the same results as previous studies. $25,28,64,65$

Figure $4 \mathrm{C}$ shows the resonance angle (internal angle) at $70.90^{\circ}$ to calculate the layer-by-layer (as in the schematic in the inset) comparisons of optical absorption spectra of multilayers in transverse-magnetic (TM) polarization. Strong absorption peaks were noted in the range 650-750 nm. The absorption peak of the Au/Cys (layer2) obviously increased compared with the $\mathrm{Cr} / \mathrm{Au}$ (layer-1); however, the absorption wavelengths in the $\mathrm{Cr} / \mathrm{Au}$ and $\mathrm{Au} /$ Cys layers were observed at absorption peaks of 677 and $688 \mathrm{~nm}$, respectively. This phenomenon may be because the amount of plasmon (interaction of interface electric field) in the inner layer of $\mathrm{Cr} / \mathrm{Au}$ (layer-1) had been transferred to the outer layer of $\mathrm{Au} / \mathrm{Cys}$ (layer-2). Therefore, the evanescent wave of the plasmon resonance propagated only in the $\mathrm{Au} / \mathrm{Cys}$ (layer-2) interface. We also examined carboxyl-GO using the visible spectrum against the whole $\mathrm{BK} 7 / \mathrm{Cr} / \mathrm{Au} / \mathrm{Cys} /$ carboxyl-GO structure in water, which showed a strong SPR band at $690 \mathrm{~nm}$.

We calculated the $\mathrm{BK} 7 / \mathrm{Cr} / \mathrm{Au} / \mathrm{Cys} /$ carboxyl-GO structure of the SPR dispersion relationship for angles of 35-90 (internal angle) as shown in Figure 4D. The resonant position of the SPR changed as the wavelength varied, indicating a change in the media interface relationship dispersion. Narrow FWHM, sharp SPR curves and minimum reflection intensity $\left(\mathrm{R}_{\min }\right)$ could be produced by making a surface of the $\mathrm{BK} 7 / \mathrm{Cr} / \mathrm{Au} / \mathrm{Cys} /$ carboxyl-GO structure. When evaluating the sensitivity of SPR sensors, the most important parameters are FWHM, SPR reflection intensity, resolution and resonant angle shift. We analyzed the relationship between FWHM of the SPR reflection intensity at different wavelengths and angles. The structure tunability had a distinct feature, in that the long wavelength shifted the SPR angle to a small value and small FWHM. In the carboxyl-GO-based SPR multilayer structure, the results showed that the dispersion curve at incident wavelengths of $770,690,650$, and $600 \mathrm{~nm}$ exhibited SPR angles of $67.25^{\circ}, 70.90^{\circ}, 76.88^{\circ}$, and $79.32^{\circ}$, respectively. The corresponding changes in FWHM were $2.18^{\circ}$, 
$4.93^{\circ}, 8.62^{\circ}, 10.05^{\circ}$, for $770,690,650$, and $600 \mathrm{~nm}$, respectively.

\section{Detection of hCG Protein Interactions in PBS Buffer}

The molecular interactions between the peptides and hCG protein in PBS buffer experiments are shown in Figure 5. The peptide-hCG interaction reaction curves are shown as a solid line and the fitted curves as a black dotted line. We injected different concentrations of $\mathrm{hCG}$ at a flow rate of $30 \mu \mathrm{L} / \mathrm{min}$ and waited for 8 minutes to observe the binding equilibrium state between peptides and hCG. Some of the most useful information that SPR can provide in peptide and hCG protein interactions is the extent to which specific amino acid side chains of proteins affect membrane association and dissociation. In addition, the kinetic constants can be directly determined from equilibrium binding responses over a range of $\mathrm{hCG}$ concentrations by fitting the data to a Langmuir adsorption isotherm.

The Langmuir model considers sorption by monolayer type and supposes that (1) adsorption occurs at specific binding sites that are localized on the surface of the complex [peptide]-[hCG] molecules, (2) all adsorption sites on the surface of the complex [peptide]-[hCG] molecules are identical, (3) no heterogeneity of the sensor chip, (4) no interactions between adjacent molecules at the surface, and (5) at high concentration $[\mathrm{hCG}]$, there will be a saturation coverage of the complex [peptide] $-[\mathrm{hCG}]$ molecules at the sensor chip. ${ }^{66-68}$

In the reaction at each concentration, we used the 1:1 Langmuir model to analyze the adsorption isotherm between peptide and hCG. Affinity constants were calculated using Biosensing Instrument software (version 2.4.4) with the use of an appropriate binding model.

Figure 5A shows the SPR binding experiments of the carboxyl-GO-based chip. The representative SPR sensorgrams at different concentrations of the injected analytes of hCG protein were $1 \mathrm{nM}, 500 \mathrm{pM}, 250 \mathrm{pM}, 100 \mathrm{pM}, 50$ pM, $10 \mathrm{pM}, 5 \mathrm{pM}, 1 \mathrm{pM}$, and $0 \mathrm{pM}$ corresponding to SPR angle shifts of $32.118,16.476,10.073,7.532,3.527,1.264$, $1.329,0.287$, and $-0.182 \mathrm{~m}^{\mathrm{o}}$, respectively. In the kinetic analysis, we injected different concentrations of hCG protein on the carboxyl-GO-based SPR chip, and the time for the reaction to reach dissociation equilibrium was about $500 \mathrm{~s}$. The kinetic fit curves corresponding to nine different concentrations of hCG protein are shown in Figure 5A. The results of the carboxyl-GO-based chip at peptide-hCG binding of association rate constant $\left(\mathrm{k}_{\mathrm{a}}\right)$, dissociation rate constant $\left(\mathrm{k}_{\mathrm{d}}\right)$, and equilibrium association constant $\left(\mathrm{K}_{\mathrm{A}}\right)$ were $7.32 \times 10^{8} \mathrm{M}^{-1} \mathrm{~S}^{-1}, 4.22 \times 10^{-3} \mathrm{~S}^{-1}$, and $17.35 \times 10^{10}$ $\mathrm{M}^{-1}$, respectively.

Figure 5B shows the results of injecting dilutions of the samples and analysis of peptide-hCG binding in the GObased SPR chip. The results showed that the hCG concentrations were $1 \mathrm{nM}, 500 \mathrm{pM}, 250 \mathrm{pM}, 100 \mathrm{pM}, 50 \mathrm{pM}, 10 \mathrm{pM}$, and $0 \mathrm{pM}$ corresponding to SPR angle shifts of 22.155, $11.557,8.334,6.106,2.467,0.809$, and $-0.253 \mathrm{~m}^{\mathrm{o}}$, respectively. In kinetic analysis of the GO-based chip, the peptidehCG interactions yielded the following rate constants for average interactions: $\mathrm{k}_{\mathrm{a}}=7.32 \times 10^{6} \mathrm{M}^{-1} \mathrm{~S}^{-1}, \mathrm{k}_{\mathrm{d}}=5.22 \times 10^{-4}$ $\mathrm{S}^{-1}$ and $\mathrm{K}_{\mathrm{A}}=14.1 \times 10^{9} \mathrm{M}^{-1}$. We analyzed the affinity constants of interactions between hCG and peptide complex structures at the carboxyl-GO and GO-based chips. The results showed that the carboxyl-GO-based chip had a higher affinity $\left(\mathrm{K}_{\mathrm{A}}\right)$ of $17.35 \times 10^{10} \mathrm{M}^{-1}$.

A linear calibration curve was plotted for the sensitivity of hCG protein concentration for the SPR responses in the carboxyl-GO and GO chips. Figure 5C shows an excellent linear response of the SPR angle shift at hCG concentrations ranging from $1 \mathrm{pM}$ to $1 \mathrm{nM}$, which is acceptable to identify hCG (normal range of hCG blood test is $<10 \mathrm{pM}$ ), and measurement reproducibility within $10 \%$. The corresponding regression equations were $f(x)=1.76+30.52 x$ with a correlation coefficient $\left(\mathrm{R}^{2}\right)$ of 0.98 for the carboxyl-GObased SPR chip, and $f(x)=2.18+20.1 x$ with a correlation coefficient of 0.97 for the GO-based SPR chip. Figure 5D shows a linear response of the SPR angle shift at low hCG concentrations ranging from $1 \mathrm{pM}$ to $100 \mathrm{pM}$. We successfully measured low detection limits of $1 \mathrm{pM}\left(\theta_{\mathrm{SPR}}=0.287 \pm\right.$ $\left.0.03 \mathrm{~m}^{\circ}\right)$ for the carboxyl-GO-based chip and $10 \mathrm{pM}\left(\theta_{\mathrm{SPR}}=\right.$ $0.81 \pm 0.1 \mathrm{~m}^{\mathrm{o}}$ ) for the GO-based chip, and the corresponding regression equations were $f(x)=0.23+73.88 x$ with $\mathrm{R}^{2}=0.97$ and $f(x)=0.29+49.67 x$ with $\mathrm{R}^{2}=0.96$, corresponding to the carboxyl-GO- and GO-based chips, respectively. The relative standard deviation was $<10 \%$ for PBS buffer $(n=3)$, which was in good agreement with that reported previously, ${ }^{21}$ indicating that the modification of carboxyl$\mathrm{GO}$ on the $\mathrm{Au}$ surface improved peptide-hCG interactions. The sensitivity and LOD of the carboxyl-GO-based chip far exceeded other detection technology studies. For example, Wang et al developed an electrochemical immunosensor based on the composite of $\mathrm{SnS}_{2}$ functionalized ligninbased porous carbons (LPCs-SnS $\mathrm{S}_{2}$ ) and gold nanoparticles (AuNPs) for the detection of hCG with a LOD of 6.4 $\mathrm{pg} / \mathrm{mL}^{48}$ and Ding et al developed a liquid crystal-based 


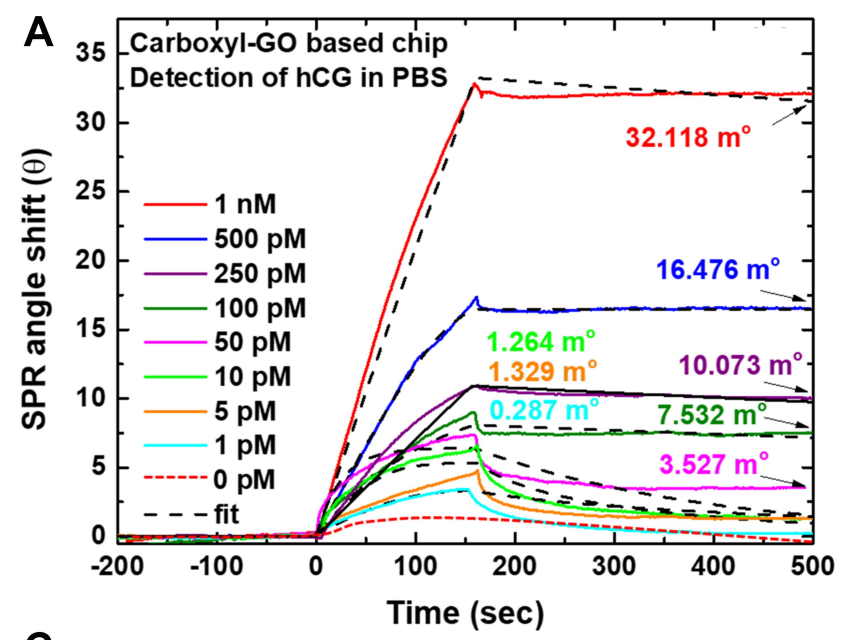

C

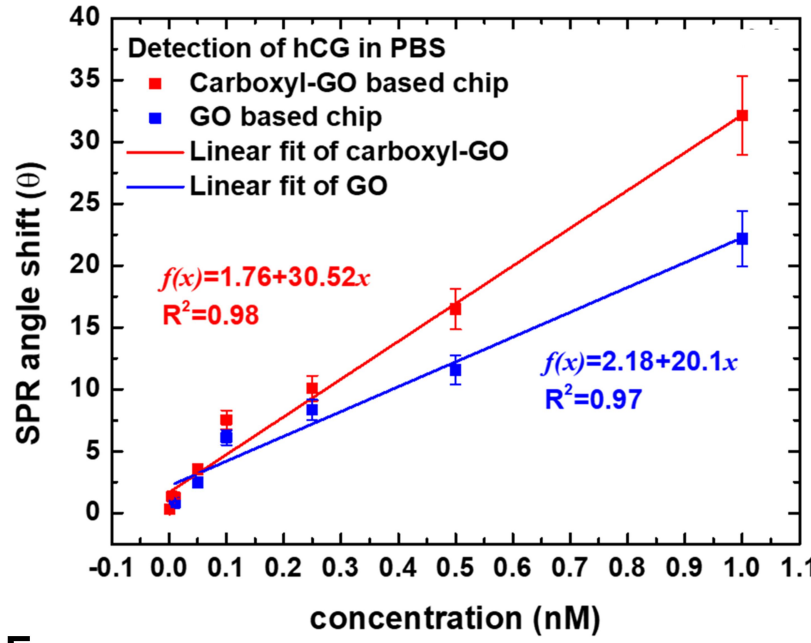

E

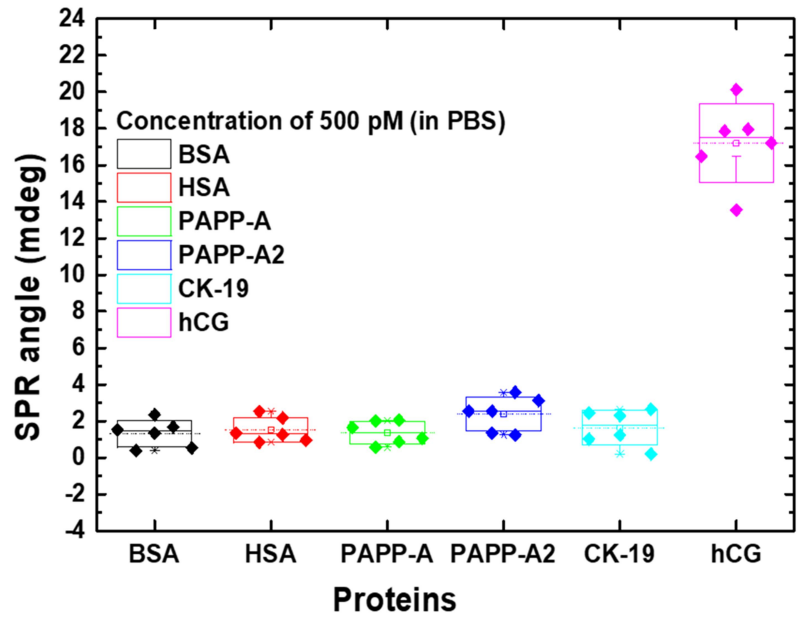

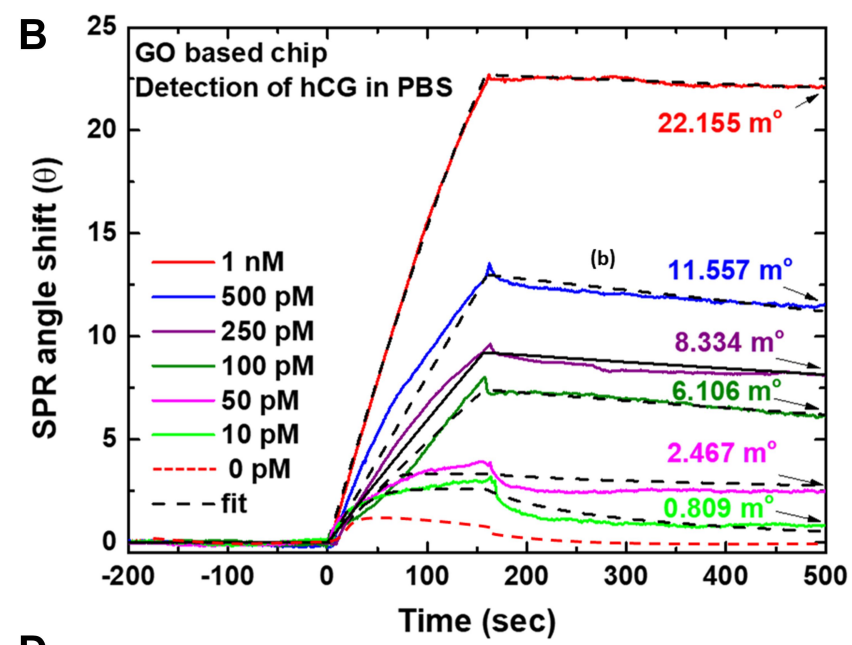

D

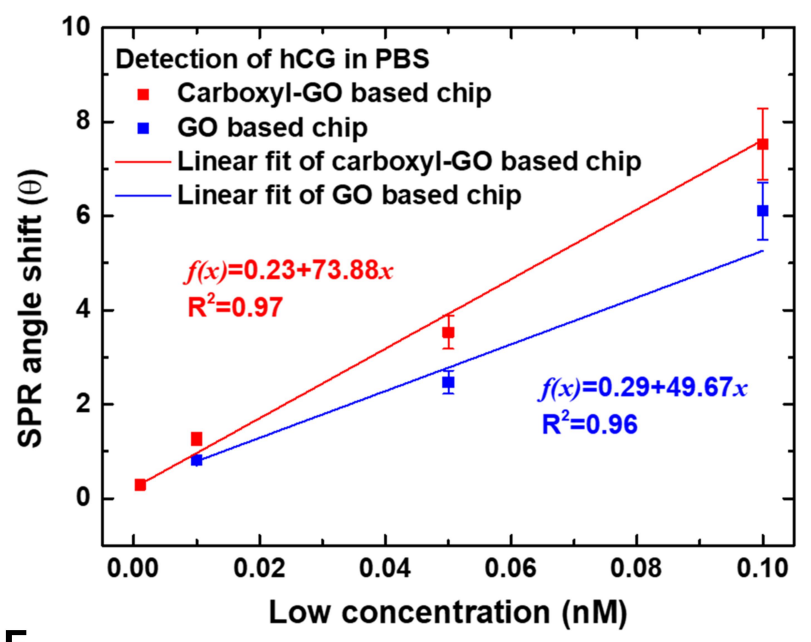

$\mathbf{F}$

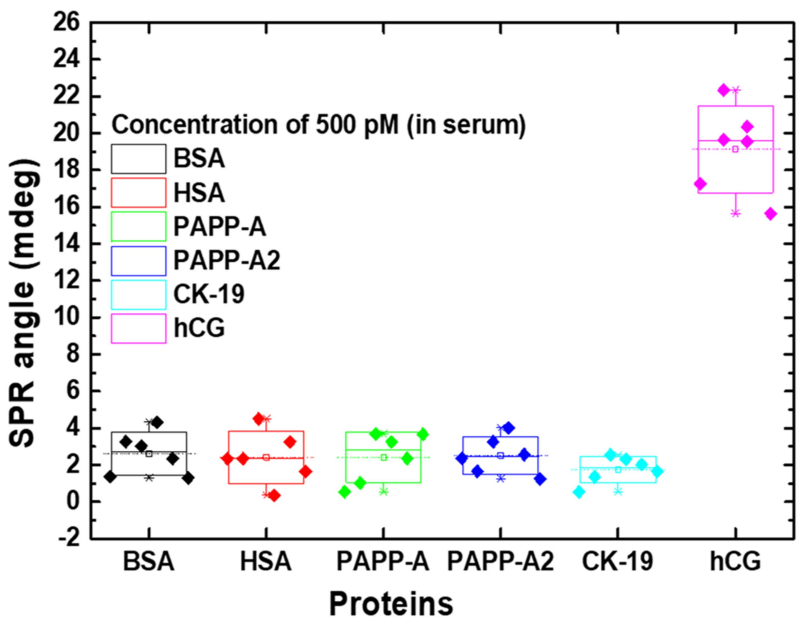

Figure 5 Sensorgrams for the SPR responses of specificity binding of peptide-hCG interactions to the (A) carboxyl-GO and (B) GO sheets immobilized SPR sensing surface. (C) Linear calibration curve based on the relationship between SPR angle and hCG protein concentration on carboxyl-GO and GO chip responses. The average SPR response to various hCG concentrations ranging from I PM to InM. (D) Linear curve at low concentration (linear range between I pM to I00 pM). The specificity of the aptasensor tested the SPR responses to interfering proteins. The SPR responses to BSA, HSA, PAPP-A, PAPP-A2, CK-19 and hCG were investigated under (E) PBS buffer and $(\mathbf{F})$ spiked 10\% serum buffer experimental conditions.

Abbreviations: SPR, surface plasmon resonance; hCG, human chorionic gonadotropin; GO, graphene oxide; Carboxyl-GO, carboxyl-graphene oxide; BSA, bovine serum albumin; HSA, human serum albumin; PAPP-A, pregnancy-associated plasma protein A; PAPP-A2, pregnancy-associated plasma protein A2; CK-I9, human cytokeratin 19; PBS, phosphate buffered saline. 
assay for use as an hCG-binding peptide aptamer with a LOD of $1 \mathrm{IU} / \mathrm{mL}(2 \mathrm{nM}) .{ }^{10}$ In addition, Xia et al developed a silver nanoparticle (AgNP) assay method to detect hCG protein, and reported a LOD of $0.4 \mathrm{mIU} / \mathrm{mL} .{ }^{69}$ Compared to the reported approaches for hCG determination (shown in Table 1), the carboxyl-GO-based biosensor demonstrated obvious merits in performance.

To investigate the selectivity (specificity) effects in the detection of various proteins, we tested interference with molecular interaction assays on the peptide probe and six different proteins at a concentration of $500 \mathrm{pM}$ each and a flow rate of $60 \mu \mathrm{L} / \mathrm{min}$ as shown in Figure $5 \mathrm{E}$ and $\mathrm{F}$. The SPR angle responses of the six different proteins were measured six times. The measured average SPR angles in the PBS buffer for BSA, HSA, PAPP-A, PAPP-A2, CK19 , and hCG proteins were 1.31, 1.52, 1.37, 2.39, 1.65,

Table I The Comparison Between Our Established Biosensor and Reported Methods

\begin{tabular}{|c|c|c|}
\hline Method & Detection Limit & Refs. \\
\hline ELISA & $\begin{array}{l}17 \mathrm{mlU} / \mathrm{mL} \text { (in urine samples). } \\
18 \mathrm{mlU} / \mathrm{mL} \text { (in serum samples). }\end{array}$ & [34] \\
\hline LC & $\begin{array}{l}\text { I IU/mL (or } 2 \mathrm{nM} \text { ) (in buffer } \\
\text { samples). }\end{array}$ & {$[10]$} \\
\hline $\begin{array}{l}\text { Gold nanoparticles } \\
\text { (Colorimetric) }\end{array}$ & $\begin{array}{l}15 \mathrm{mlU} / \mathrm{mL} \text { (or } 1.5 \mathrm{ng} / \mathrm{mL} \text { ) (in buffer } \\
\text { samples). }\end{array}$ & {$[22]$} \\
\hline $\begin{array}{l}\text { Fluorescent } \\
\text { (graphene oxide) }\end{array}$ & $20 \mathrm{mIU} / \mathrm{mL}$ (in buffer samples). & [38] \\
\hline $\begin{array}{l}\text { Electrochemistry } \\
\text { (LPCs-SnS2 and } \\
\text { AuNPs) }\end{array}$ & $6.4 \mathrm{pg} / \mathrm{mL}$ (in serum samples). & [37] \\
\hline $\begin{array}{l}\text { Electrochemistry } \\
\text { (silver } \\
\text { nanoparticles) }\end{array}$ & $0.4 \mathrm{mlU} / \mathrm{mL}$ (in serum samples). & {$[52]$} \\
\hline $\begin{array}{l}\text { SPR (graphene } \\
\text { oxide) }\end{array}$ & $\begin{array}{l}0.065 \mathrm{nM} \text { (or } 3.25 \mathrm{ng} / \mathrm{mL}, 32.5 \\
\mathrm{mlU} / \mathrm{mL} \text { ) (in buffer samples). }\end{array}$ & {$[21]$} \\
\hline $\begin{array}{l}\text { SPR (carboxyl- } \\
\text { graphene oxide) }\end{array}$ & $\begin{array}{l}\text { I. } 15 \mathrm{pM} \text { (or } 0.575 \mathrm{mlU} / \mathrm{mL} \text { ) (in serum } \\
\text { samples for normal pregnant). }\end{array}$ & [23] \\
\hline $\begin{array}{l}\text { SPR (carboxyl- } \\
\text { graphene oxide) }\end{array}$ & $\begin{array}{l}\text { I pM (or } 0.5 \mathrm{mIU} / \mathrm{mL} \text { ) (in buffer } \\
\text { samples). } \\
\text { I.9 pM (or } 0.95 \mathrm{mlU} / \mathrm{mL} \text { ) (in clinical } \\
\text { serum samples for women with fetal } \\
\text { Down's syndrome). }\end{array}$ & $\begin{array}{l}\text { This } \\
\text { work }\end{array}$ \\
\hline
\end{tabular}

Abbreviations: ELISA, enzyme-linked immunosorbent assay; LC, liquid crystal; AuNPs, gold nanoparticles; $\mathrm{LPCs}_{\mathrm{S}} \mathrm{SnS}_{2}, \mathrm{SnS}_{2}$ functionalized lignin-based porous carbons; SPR, surface plasmon resonance. and $17.19 \mathrm{~m}^{\circ}$, respectively, as shown in Figure 5E. In addition, the average SPR angle responses in BSA, HSA, PAPP-A, PAPP-A2, CK-19, and hCG with spiked 10\% serum were $2.60,2.41,2.42,2.51,1.74$, and $19.13 \mathrm{~m}^{\circ}$, respectively, as shown in Figure 5F. The selectivity results showed that the SPR signals of the other proteins were markedly smaller than that of hCG protein. This assay had a high specificity for peptides with an hCG protein binding site in a complex serum environment with many ionic and neutral analytes and no binding reaction with the other interfering proteins. The interference signals of the BSA, HSA, PAPP-A, PAPP-A2 and CK-19 proteins were close to that of a blank solution, which indicated the high selectivity of the carboxyl-GO-based SPR aptasensor.

\section{Detection of hCG Protein to Screen Fetal DS in Clinical Serum Samples}

In the clinical serum sample experiment, we used serum samples from normal pregnant women (NPW) and women with fetal Down's syndrome (FDSW) for hCG protein screening analysis using the carboxyl-GO-based SPR aptasensors. The hCG concentration in the serum samples was measured by ELISA, and the concentrations were 163.64, $170.47,126.50,185.34,381.74,674.83$, 488.92, 418.40, 430.82 and $525.65 \mathrm{nM}$ for NPW-1, NPW-2, NPW-3, NPW-4, FDSW-1, FDSW-2, FDSW-3, FDSW-4, FDSW5 , and FDSW-6, respectively.

Figures 6 and 7 show representative SPR sensorgrams illustrating the expression of peptide-carboxyl-GO chips for serum samples in the NPW and FDSW groups, with different dilutions. The results showed that the hCG concentration in the healthy women (NPW group) was within the normal range (163.64, 170.47, 126.50 and $185.34 \mathrm{nM})$. Therefore, we diluted the serum of four healthy women by $5 \mathrm{k}$-fold and $10 \mathrm{k}$-fold to analyze the hCG concentration. In addition, the serum samples of the women with fetal Down's syndrome (FDSW group) had originally higher hCG concentration (381.74, 674.83, 488.92, 418.40, 430.82 and 525.65 nM), so we diluted their samples by $5 \mathrm{k}$-fold, $10 \mathrm{k}$-fold, $25 \mathrm{k}$-fold, $50 \mathrm{k}$-fold, 100k-fold and 200k-fold. We converted the dilution ratio into hCG concentration, and evaluated and analyzed the angle shift of SPR at different dilutions.

The results showed that the hCG protein in the serum samples was bound to the specific peptide (association phase) starting from the injection point at $0 \mathrm{sec}$ and dissociation phase at $200 \mathrm{sec}$, reaching equilibrium after approximately $500 \mathrm{sec}$. Figure 6A-D shows serum samples of the NPW 

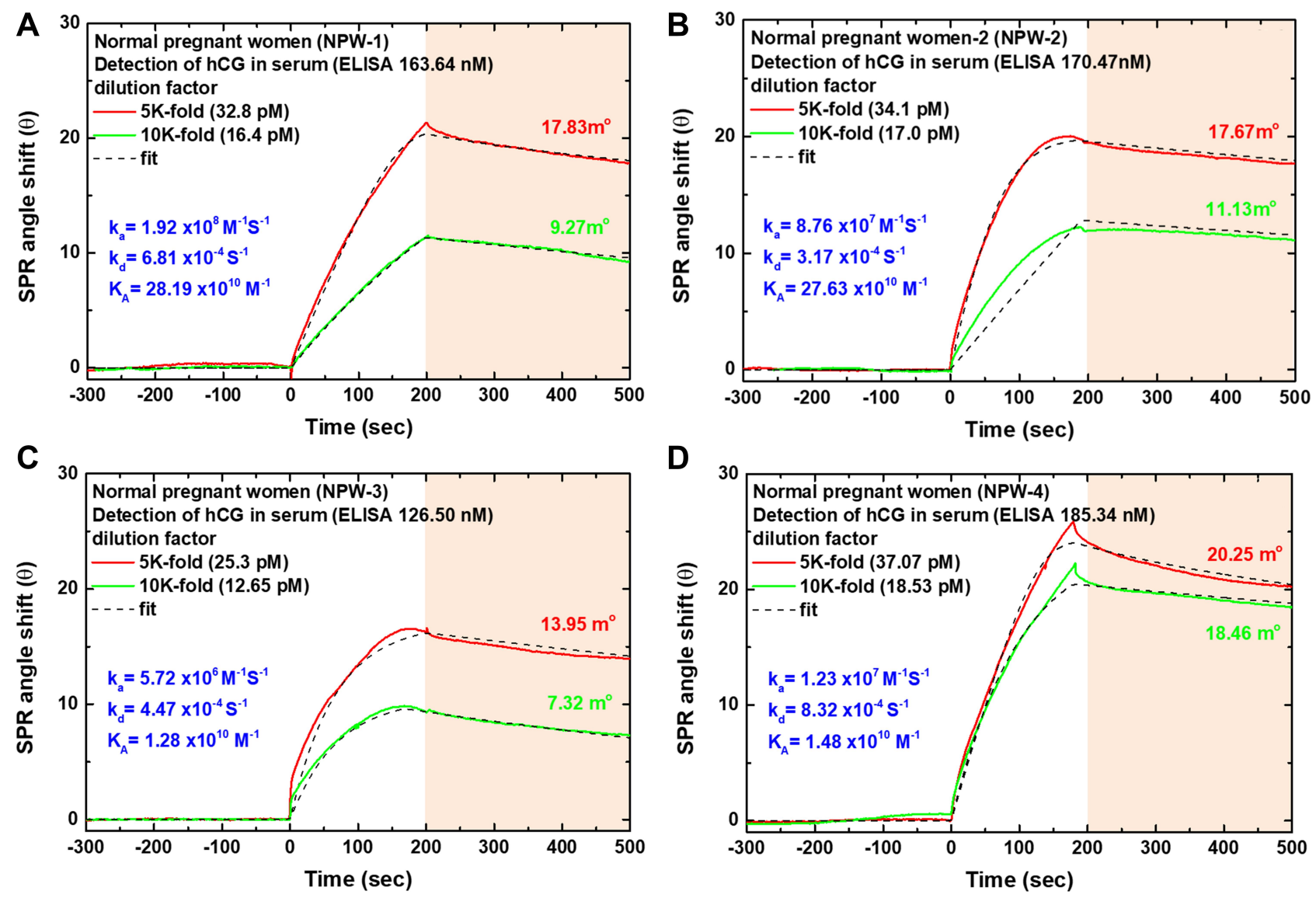

Figure 6 SPR sensorgram data showing a comparison of binding interactions of a peptide probe with hCG protein in clinical serum samples. The hCG concentrations in the women with normal pregnancy (NPW) were (A) $163.64 \mathrm{nM}$ at 15 weeks, (B) $170.47 \mathrm{nM}$ at 12 weeks, (C) $126.50 \mathrm{nM}$ at 14 weeks, and (D) I85.34 nM at I7 weeks. Abbreviations: SPR, surface plasmon resonance; hCG, human chorionic gonadotropin; NPW, women with normal pregnancy.

group at 15 weeks (NPW-1), 12 weeks (NPW-2), 14 weeks (NPW-3), and 17 weeks (NPW-4), respectively. Figure 6A shows that the serum concentrations were diluted $5 \mathrm{k}$-fold $(32.8 \mathrm{pM})$ and $10 \mathrm{k}$-fold $(16.4 \mathrm{pM})$ relative to SPR angle shifts of 17.83 and $9.27 \mathrm{~m}^{\mathrm{o}}$, respectively. In Figure 6B, the serum concentrations at 12 weeks in the NPW group (NPW-2) were diluted 5k-fold (34.1 pM) and 10k-fold $(17.0 \mathrm{pM})$ relative to SPR angle shifts of 17.67 and $11.13 \mathrm{~m}^{\mathrm{o}}$, respectively. Figure $6 \mathrm{C}$ shows that the serum concentrations were diluted $5 \mathrm{k}$-fold $(25.3 \mathrm{pM})$ and $10 \mathrm{k}$-fold (12.65 $\mathrm{pM}$ ) relative to SPR angle shifts of 13.95 and $7.32 \mathrm{~m}^{\circ}$, respectively. Figure $6 \mathrm{D}$ shows that the serum concentrations were diluted 5k-fold (37.07 pM) and 10k-fold (18.53 pM) relative to SPR angle shifts of 20.25 and $18.46 \mathrm{~m}^{\circ}$, respectively. The results of the fitting kinetics analysis of the serum samples in NPW-1, NPW-2, NPW-3, and NPW-4 showed that the carboxyl-GO chip had high affinity binding constants $\left(\mathrm{K}_{\mathrm{A}}\right)$ of $28.19,27.63,1.28$ and $1.48 \times 10^{10} \mathrm{M}^{-1}$, respectively.

The SPR sensorgram characteristics of the FDSW group at different serum dilutions are shown in Figure 7A-F. In the
FDSW group with serum diluted by $5 \mathrm{k}$-fold, the results showed that the SPR angle shifts of FDSW-1, FDSW-2, FDSW-3, FDSW-4, FDSW-5 and FDSW-6 were 41.88, $66.69,44.48,30.18,32.33$ and $50.05 \mathrm{~m}^{\circ}$, which were relative to serum hCG concentrations of $76.4,135,97.8,83.7,86.2$ and $105.1 \mathrm{pM}$, respectively. The results showed that the FDSW group with serum diluted by 10k-fold had SPR angle shifts of 21.76, 21.56, 19.26, 17.79, 21.37 and $33.46 \mathrm{~m}^{\mathrm{o}}$ for the FDSW-1, FDSW-2, FDSW-3, FDSW-4, FDSW-5 and FDSW-6 women, respectively. A comparison between the measured serum hCG concentrations at $5 \mathrm{k}$-fold and 10k-fold dilution factors showed that the SPR sensorgrams at angle shifts in the NPW group were less than those in the FDSW group. These results showed that the SPR angle shifts of the FDSW group were greater than those of the NPW group by 4.8 times in the $5 \mathrm{k}$-fold serum dilution factor. In addition, the level of hCG in the serum was more than twice that of the NPW, which may indicate an increased risk of fetal DS. Moreover, the experimental results showed that the FDSW group at a 200k-fold dilution factor of serum had 



D
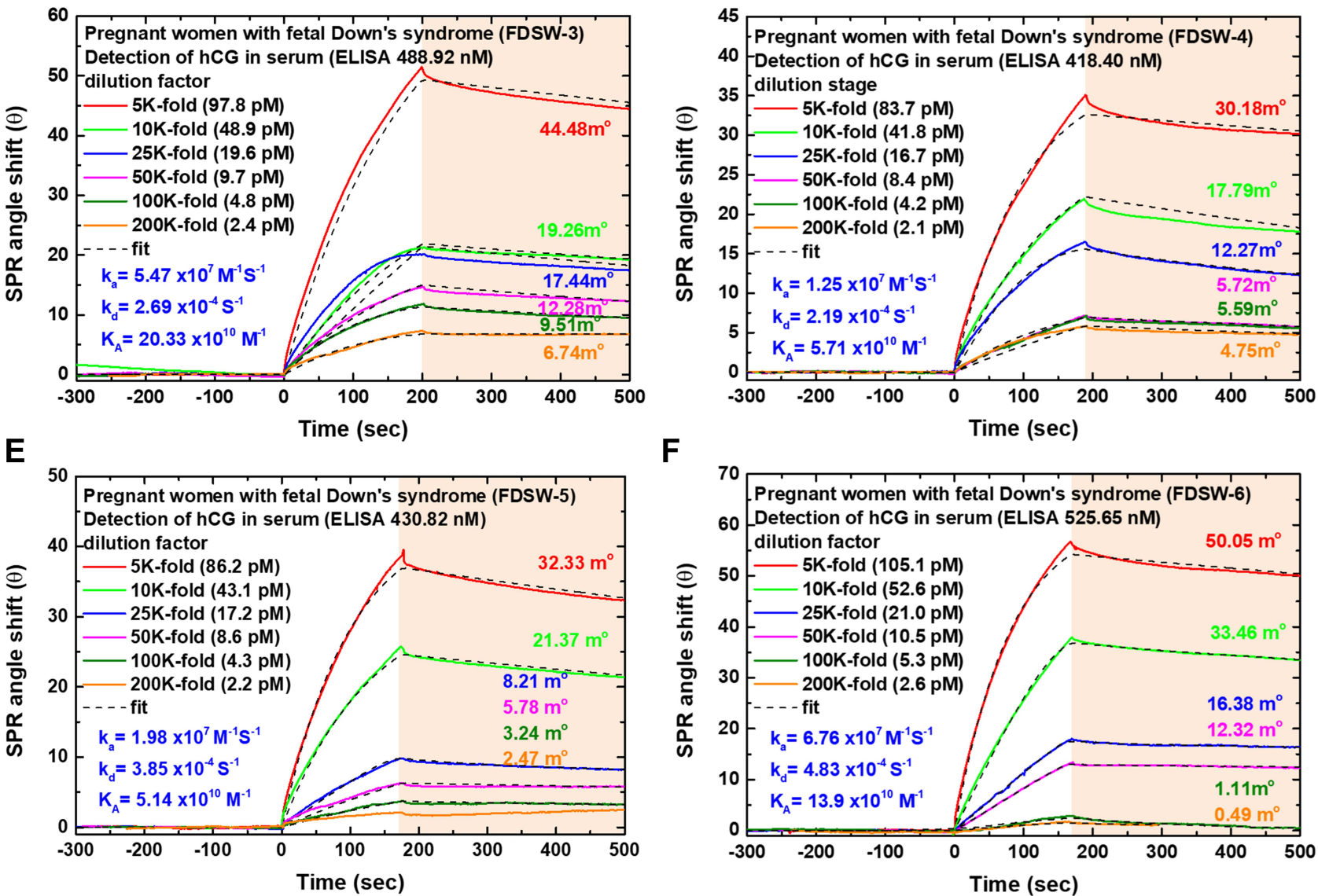

Figure 7 SPR sensorgram data showing a comparison of binding interactions of a peptide probe with hCG protein in clinical serum samples. The hCG concentrations in the women with fetal Down's syndrome (FDSW) were (A) $381.74 \mathrm{nM}$ at I9 weeks, (B) $674.83 \mathrm{nM}$ at I4 weeks, (C) $488.92 \mathrm{nM}$ at I2 weeks, and (D) 4 I8.47 nM at I2 weeks, (E) $430.82 \mathrm{nM}$ at 16 weeks, and $(\mathbf{F}) 525.65 \mathrm{nM}$ at 17 weeks.

Abbreviations: SPR, surface plasmon resonance; hCG, human chorionic gonadotropin; FDSW, women with fetal Down's syndrome.

hCG concentrations of 1.9, 3.4, 2.4, 2.1, 2.2 and 2.6 $\mathrm{pM}$ in the FDSW-1, FDSW-2, FDSW-3, FDSW-4, FDSW-5 and FDSW-6 women, respectively, corresponding to SPR angle shifts of $0.97,1.25,6.74,4.75,2.47$ and $0.49 \mathrm{~m}^{\circ}$.

We analyzed the serum hCG concentrations at different dilutions and evaluated the equilibrium and kinetic constants of the fitted curve. The results of the fitting kinetics analysis of the serum samples in the FDSW-1, FDSW-2, FDSW-3, FDSW-4, FDSW-5 and FDSW-6 women showed that the carboxyl-GO chip had high affinity binding constants $\left(\mathrm{K}_{\mathrm{A}}\right)$ of $7.22,9.39$, 20.33, 5.71, 5.14 and $13.9 \times 10^{10} \mathrm{M}^{-1}$, respectively. This showed that the detection of hCG protein in the clinical serum samples and in the PBS buffer samples to fit the experimental 
data had the same high sensitivity and high affinity performance as the carboxyl-GO chip. Moreover, the experimental results showed that the carboxyl-GO functionalized surface exhibited good specificity and could be regenerated more than 20 times. The stability of the resonance angle of the carboxyl-GO-based SPR aptasensor in clinical serum samples to detect the repeated regeneration of hCG protein was within $12 \%$. The storage stability of the biosensor was up to $85 \sim 88 \%$ after storage for 30 days in a refrigerator at $4^{\circ} \mathrm{C}$.

\section{The Calibration Curve and Assay Specificity of Fetal DS Screening}

Taken together, the above experiments showed that the peptide-carboxyl-GO film basically affected the sensitivity of the SPR biosensor. Under different clinical serum sample experimental conditions, the angle shift of the SPR signal proportionally increased after the injection of different serum concentrations of hCG, ranging from $1.9 \mathrm{pM}$ to $135 \mathrm{pM}$ ( $5 \mathrm{k}$ to $200 \mathrm{k}$-fold diluted). The results showed the concentration linear range had a regression equation of $f(x)=-2.73+0.48 x$ and a correlation coefficient $\left(R^{2}\right)$ of 0.96 , where $x$ is the hCG protein concentration, and $f(x)$ is the SPR angle shift $\left(\mathrm{m}^{\circ}\right)$. The linear regression had higher linearity and error bars representing the standard deviation of three replicates $(n=3)$ as shown in Figure 8A. The calibration curve had a dynamic response range between 1.9 and $135 \mathrm{pM}$, which is useful for analyzing clinical samples, to determine the hCG concentration in serum. The LOD value of hCG concentration in serum with the
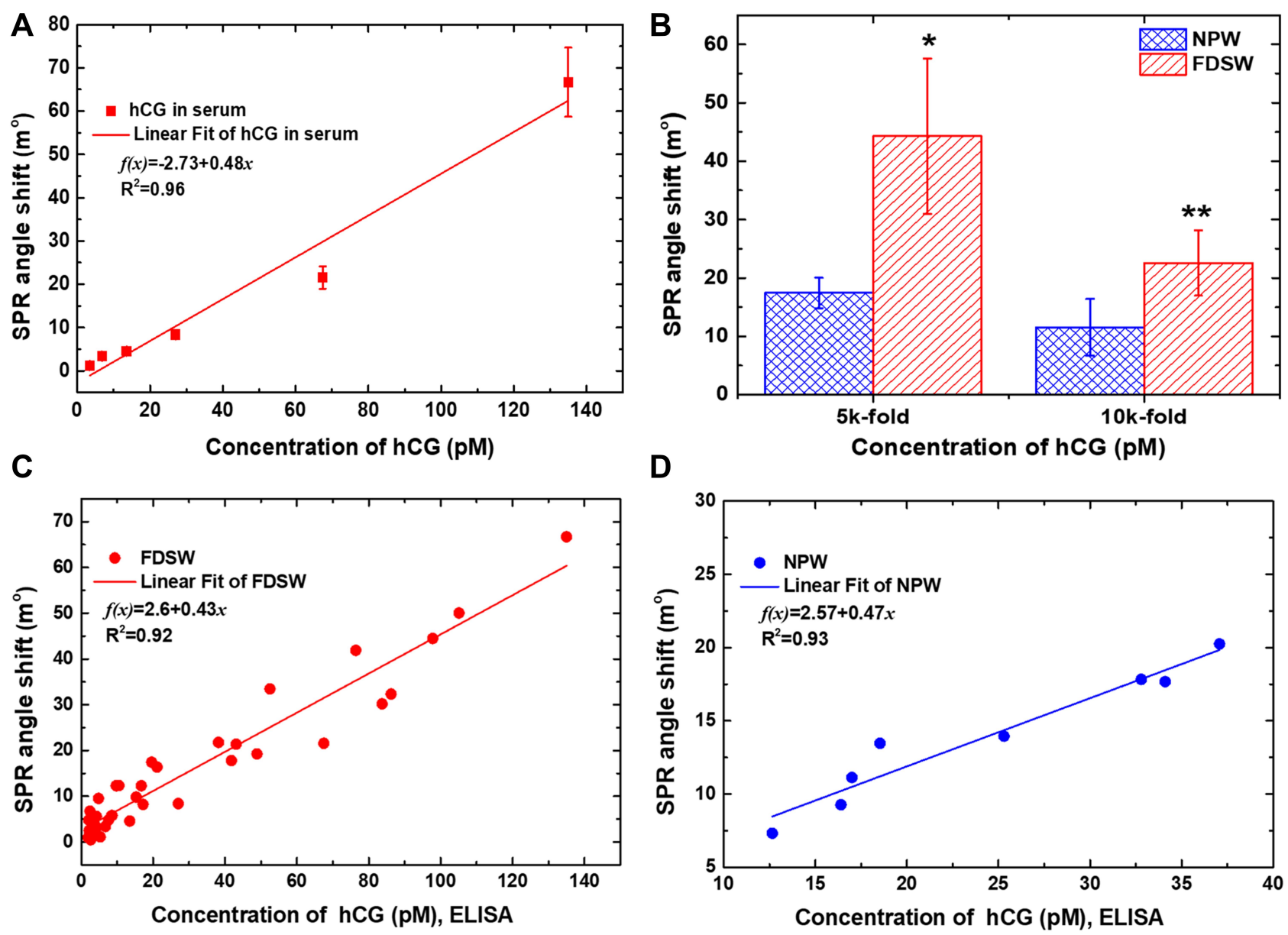

Figure 8 Plot of the results of the calibration curve of clinical serum samples and analysis of SPR angle shift with assay specificity using the peptide-based SPR biosensor for carboxyl-GO film. (A) Calibration curves of average SPR detection with various hCG protein concentrations ranging from 1.9 pM to 135 pM in the serum samples. The error bars represent the SD of three replicates. (B) Correlation between two variables of the NPW and FDSW groups in serum samples. The proportion of healthy NPW group were significantly reduced in the $5 \mathrm{k}$ and $10 \mathrm{k}$-fold dilution factor compared to the FDSW group. Results are expressed as means \pm SD of three independent experiments, each performed in triplicate. * and ** significantly different from NPW group, $P=0.004$ and $P=0.013$, respectively. Correlating SPR and ELISA concentrations at (C) for patients of FDSW group $\left(R^{2}=0.92\right)$ and $(D)$ for healthy pregnant (NPW group) $\left(R^{2}=0.93\right)$ samples.

Abbreviations: SPR, surface plasmon resonance; hCG, human chorionic gonadotropin; SD, Down's syndrome; NPW, women with normal pregnancy; FDSW, women with fetal Down's syndrome. 
carboxyl-GO chip was calculated as $1.9 \mathrm{pM}\left(\theta_{\mathrm{SPR}}=0.97 \pm\right.$ $0.1 \mathrm{~m}^{\mathrm{o}}$ ), which showed high specificity for the determination of hCG protein in the serum samples.

In the assay specificity of DS screening, we used $5 \mathrm{k}$ and $10 \mathrm{k}$ dilution factors to analyze the hCG concentration in serum in the FDSW and NPW groups as shown in Figure 8B. Consistently, the SPR angle shift level was greater in the FDSW group than in the NPW group, mirroring the fetal DS expression data. To compare differences between NPW and FDSW, Student's $t$-tests were used. All results are reported as mean \pm standard deviation unless otherwise stated. Statistical analysis was performed with PASW Statistics 18.0 (SPSS Institute, Chicago, IL). In the serum with 5k-fold dilution factor, the hCG protein levels in the FDSW group were increased compared to those in the NPW group, and the women with a serum hCG concentration $>76.4 \mathrm{pM}$ had a higher correlation with fetal DS compared to the NPW. This result showed that the women with an SPR angle shift $>17.43 \pm 2.60 \mathrm{~m}^{\circ}$ were more significantly associated with fetal DS compared to the NPW. The mean 5k-fold hCG SPR angle was $17.43 \pm 2.60 \mathrm{~m}^{\circ}$ in the NPW and $44.27 \pm 13.29 \mathrm{~m}^{\circ}$ in the FDSW $(P=0.004)$. In the serum with $10 \mathrm{k}$-fold dilution factor, the hCG protein levels in the FDSW group were increased compared to those in the NPW, and the women with a serum hCG concentration $>38.2$ pM were more significantly associated with fetal DS compared to the NPW. Compared to the NPW, the women with an SPR angle shift $>11.55 \pm 4.87 \mathrm{~m}^{\circ}$ were more significantly associated with fetal DS. The mean $10 \mathrm{k}$-fold hCG SPR angle was $11.55 \pm 4.87 \mathrm{~m}^{\mathrm{o}}$ in the NPW and $22.53 \pm 5.58 \mathrm{~m}^{\circ}$ in the FDSW $(P=0.013)$. The results of these experiments showed that using a $5 \mathrm{k}$-fold dilution of the serum samples resulted in less interference and lower non-specific adsorption with high linearity. Moreover, the differential diagnosis of the FDSW compared to the NPW group using a 5kfold dilution factor was better than that of a 10k-fold dilution factor, consistent with the elevated concentrations of $\mathrm{hCG}$ in pregnant women with fetal DS. ${ }^{70,71}$

Figure $8 \mathrm{C}$ and $\mathrm{D}$ show the linear correlation between the results of hCG concentration in the serum of the FDSW and NPW groups obtained by the two methods (SPR and ELISA). A standard curve was constructed from serial dilutions of serum samples. Figure $8 \mathrm{C}$ shows the linear regression with serum concentrations from $5 \mathrm{k}$ to $200 \mathrm{k}$-fold dilution, and all samples showed the correlation of concentration with SPR angle shift. A linear correlation was shown between the results of hCG concentration in the serum of the FDSW group obtained by the SPR and ELISA methods. The linear regression equation for the assay response of hCG was $f(x)=2.6+0.43 \mathrm{x}$ with $\mathrm{R}^{2}=0.92$, where $\mathrm{y}$ and $\mathrm{x}$ are the responses in SPR angle shift and the analyte concentration (ELISA) in serum samples, respectively. The results of the FDSW group showed quite a good correlation between hCG concentration as measured with the SPR and ELISA methods in the FDSW group, with good assay reproducibility. Figure $8 \mathrm{D}$ shows the linear correlation between the results of hCG concentration in the serum of the NPW group, obtained by the SPR and ELISA methods. The linear regression equation for the assay response of hCG was $f(x)=2.57+0.47 \mathrm{x}$ and a $0.93 \mathrm{R}^{2}$ correlation for healthy women (NPW group) regarding response values obtained by the SPR and ELISA methods. In short, these results suggested that the SPR aptasensor had similar sensitivity to a commercial ELISA kit in quantifying hCG in serum samples. However, the newly developed carboxyl-GO-based SPR aptasensor was more rapid, had high sensitivity, was a more valuable and reproducible tool for the quantitative determination of hCG in serum samples than ELISA. Moreover, the results showed that the carboxyl-GO-based SPR aptasensor was highly specific to detect hCG.

\section{Conclusions}

We successfully developed a carboxyl-GO-based SPR aptasensor that can be used to detect $\mathrm{hCG}$ protein in serum samples from pregnant women with high sensitivity and high affinity to precisely screen DS. The carboxyl-GO film had a biocompatible surface beneficial for the adsorption of covalently linked peptides in biosensor technology. We observed a significantly higher number of SPR angles present in the FDWS group compared to the NPW group from $5 \mathrm{k}$ and $10 \mathrm{k}$-fold dilution factors. The results from this study at $5 \mathrm{k}$-fold dilution factor showed that an SPR angle shift $>17.43 \pm 2.60 \mathrm{~m}^{\circ}$ indicated a higher risk of developing fetal DS. The binding kinetic rate constants of $\mathrm{K}_{\mathrm{A}}$ in clinical serum samples exhibited high affinity at interactions of peptides and hCG protein at approximately $1.28 \sim 28.19 \times 10^{10} \mathrm{M}^{-1}$. In sensitivity analysis, the detection limits of the carboxyl-GO-based SPR aptasensor were $1 \mathrm{pM}$ for the buffer samples and $1.9 \mathrm{pM}$ for the serum samples. This is approximately several orders of magnitude lower than that of conventional SPR and GO-based biosensors, indicating the feasibility of using our proposed method to screen for DS. The screening for fetal DS in the $5 \mathrm{k}$-fold dilution factor showed a statistically significant difference $(P=0.004)$. In particular, the progress of early 
prenatal molecular diagnosis can be improved with carboxyl-GO-based SPR aptasensors without a label, and preprocessing of the samples showed very high sensitivity, specificity, and reproducibility against hCG protein in serum samples from pregnant women. The results, which agree with those obtained by ELISA, showed that the tested SPR had remarkable accuracy and specificity as a serum hCG protein assay. This technology shows promise for its adaptation with similar specific, high affinity aptamers towards the detection of other predictive pregnancy-related biomarkers.

\section{Data Sharing Statement}

The datasets generated for this study are available on request to the corresponding author.

\section{Ethics Statement}

The authors would like to thank Mackay Hospital, Taipei, Taiwan. This work was approved by the Institutional Review Board (IRB) of Mackay Hospital for Human Clinical Trials (Permit Numbers: 15MMHIS020, 15MMHIS115 and 17MMHIS185). All experiments were performed in compliance with the relevant laws and institutional guidelines, and the Human Subjects Research Ethics Committee of Mackay Memorial Hospital approved the experiments. Informed consent was obtained from all of the enrolled women for the collection and examination of clinical samples. All personal identifiers were anonymized prior to analysis. This manuscript does not involve mouse cell line experiments.

\section{Funding}

This study was supported by the Ministry of Science and Technology of the Republic of China (ROC), Taiwan, for financially supporting this research under Contract No. MOST 105-2221-E-003-027, MOST 106-2221-E-003020, MOST 107-2221-E-003-009, MOST 108-2221E-003 -020 -MY3, MOST 109-2221-E-003-028-MY3 and also Mackay Hospital (Project No. MMH-CT-10505).

\section{Disclosure}

The author reports no conflicts of interest in this work. Conflict of Interest Statement: The authors declare that the research was conducted in the absence of any commercial or financial relationships that could be construed as a potential conflict of interest.

\section{References}

1. Dávalos A, Miguel M, Bartolomé B, López-Fandiño R. Antioxidant activity of peptides derived from egg white proteins by enzymatic hydrolysis. J Food Prot. 2004;67:1939-1944. doi:10.4315/0362028X-67.9.1939

2. Kitts DD, Weiler K. Bioactive proteins and peptides from food sources. Applications of bioprocesses used in isolation and recovery. Curr Pharm. 2003;9:1309-1323. doi:10.2174/1381612033454883

3. Steiner H, Hultmark D, Engström Å, Bennich H, Boman HG. Sequence and specificity of two antibacterial proteins involved in insect immunity. Nature. 1981;292:246-248. doi:10.1038/292246a0

4. Brigati JR, Petrenko VA. Thermostability of landscape phage probes Anal Bioanal Chem. 2005;382:1346-1350. doi:10.1007/s00216-0053289-y

5. Tao K, Makam P, Aizen R, Gazit E. Self-assembling peptide semiconductors. Science. 2017;358:eaam9756. doi:10.1126/science. aam9756

6. Zhao X, Pan F, Lu JR. Recent development of peptide self-assembly. Pro Nat Sci. 2008;18:653-660.

7. Puiua M, Bala C. Peptide-based biosensors: from self-assembled interfaces to molecular probes in electrochemical assays. Bioelectrochem. 2017;120:66-75. doi:10.1016/j.bioelechem.2017.11.009

8. de La Rica R, Pejoux C, Matsui H. Assemblies of functional peptides and their applications in building blocks for biosensors. Adv Funct Mater. 2011;21:1018-1026.

9. Liu Q, Wang J, Boyd BJ. Peptide-based biosensors. Talanta. 2015;136:114-127. doi:10.1016/j.talanta.2014.12.020

10. Ding X, Yang KL. Antibody-free detection of human chorionic gonadotropin by use of liquid crystals. Anal Chem. 2013;85:10710-10716. doi:10.1021/ac400732n

11. Dover JE, Hwang GM, Mullen EH, Prorok BC, Suh SJ. Recent advances in peptide probe-based biosensors for detection of infectious agent. J Microbiol Methods. 2009;78:10-19. doi:10.1016/j.mimet.2009.04.008

12. Otari SV, Kumar M, Anwar MZ, et al. Rapid synthesis and decoration of reduced graphene oxide with gold nanoparticles by thermostable peptides for memory device and photothermal applications. Sci Rep. 2017;7:1-14. doi:10.1038/s41598-017-10777-1

13. Holt BD, Arnold AM, Sydlik SA. Peptide-functionalized reduced graphene oxide as a bioactive mechanically robust tissue regeneration scaffold. Polym Int. 2017;66:1190-1198. doi:10.1002/pi.5375

14. He X, Zhang F, Liu J, Fang G, Wang S. Homogenous graphene oxide-peptide nanofiber hybrid hydrogel as biomimetic polysaccharide hydrolase. Nanoscale. 2017;9:18066-18074. doi:10.1039/C7NR06525F

15. Wang J, Ouyang Z, Li J, Zhang P, Wei G, Su Z. Self-assembled peptide nanofibers on graphene oxide as a novel nanohybrid for biomimetic mineralization of hydroxyapatite. Carbon. 2015;89:20-30. doi:10.1016/j.carbon.2015.03.024

16. Mizutaru T, Marzun G, Kohsakowski S, et al. Peptide cross-linkers: immobilization of platinum nanoparticles highly dispersed on graphene oxide nanosheets with enhanced photocatalytic activities. ACS Appl Mater Interfaces. 2017;9:9996-10002. doi:10.1021/acsami.6b16765

17. Lim SK, Chen P, Lee FL, Moochhala S, Liedberg B. Peptideassembled graphene oxide as a fluorescent turn-on sensor for lipopolysaccharide (endotoxin) detection. Anal Chem. 2015;87:9408-9412. doi:10.1021/acs.analchem.5b02270

18. Lin C, Xi G, Li T, Wang X, Chen T. Covalent linking peptide to hydrothermally reduced graphene oxide for ultrasensitive detection of matrix metalloproteinase 9. Appl Nanosci. 2017;7:723-730. doi:10.1007/s13204-017-0613-8

19. Li Y, Zhang W, Zhang L, Li J, Su Z, Wei G. Sequence-designed peptide nanofibers bridged conjugation of graphene quantum dots with graphene oxide for high performance electrochemical hydrogen peroxide biosensor. Adv Mater Interfaces. 2017;4:1600895. doi:10.1002/admi.201600895 
20. Liang A, Li C, Li D, Luo Y, Wen G, Jiang Z. A facile and sensitive peptide-modulating graphene oxide nanoribbon catalytic nanoplasmon analytical platform for human chorionic gonadotropin. Int J Nanomedicine. 2017;12:8725-8734. doi:10.2147/IJN.S149536

21. Chiu NF, Kuo CT, Lin TL, Chang CC, Chen CY. Ultra-high sensitivity of the non-immunological affinity of graphene oxide-peptide-based surface plasmon resonance biosensors to detect human chorionic gonadotropin. Biosens Bioelectron. 2017;94:351-357. doi:10.1016/j. bios.2017.03.008

22. Nurrohman DT, Wang YH, Chiu NF. Exploring graphene and MoS2 chips based surface plasmon resonance biosensors for diagnostic applications. Front Chem. 2020;8:728-744.

23. Chang CC, Chen $\mathrm{CP}$, Lee $\mathrm{CH}$, Chen $\mathrm{CY}$, Lin CW. Colorimetric detection of human chorionic gonadotropin using catalytic gold nanoparticles and a peptide aptamer. Chem Commun. 2014;50:14443. doi:10.1039/C4CC06366J

24. Chiu NF, Kuo CT, Chen CY. High-affinity carboxyl-graphene oxide-based SPR aptasensor for the detection of hCG protein in clinical serum samples. Int $J$ Nanomed. 2019;14:4833-4847. doi:10.2147/IJN.S208292

25. Chiu NF, Lin TL, Kuo CT. Highly sensitive carboxyl-graphene oxide-based surface plasmon resonance immunosensor for the detection of lung cancer for cytokeratin 19 biomarker in human plasma. Sens Actuators B Chem. 2018;265:264-272. doi:10.1016/j. snb.2018.03.070

26. Hossain MB, Islam MM, Abdulrazak LF, Rana MM, Akib TBA, Hassan M. Graphene-coated optical fiber SPR biosensor for BRCA1 and BRCA2 breast cancer biomarker detection: a numerical design-based analysis. Photonic Sensors. 2020;10:67-79. doi:10.1007/ s13320-019-0556-7

27. Lee J, Takemura K, Park EY. Plasmonic/magnetic graphene-based magnetofluoro-immunosensing platform for virus detection. Sensor Actuator B Chem. 2018;276:254-261. doi:10.1016/j.snb.2018.08.124

28. Omar NAS, Fen YW, Abdullah J, et al. Quantitative and selective surface plasmon resonance response based on a reduced graphene oxide-polyamidoamine nanocomposite for detection of dengue virus e-proteins. Nanomaterials. 2020;10:569. doi:10.3390/nano10030569

29. Chiu NF, Huang TY, Kuo CC, Lee WC, Hsieh MH, Lai HC, Singlelayer graphene based SPR biochips for tuberculosis bacillus detection. Proc. SPIE 8427, Biophotonics: photonic solutions for better health care III; May 8, 2012; 84273M. doi: 10.1117/12.922698

30. Mudgal N, Yupapin P, Ali J, Singh G. BaTiO3-graphene-affinity layer-based surface plasmon resonance (SPR) biosensor for pseudomonas bacterial detection. Plasmonics. 2020;15:1221-1229. doi:10.1007/s11468-020-01146-2

31. Anas N, Fen YW, Omar NAS, Daniyal WMEMM, Ramdzan NSM, Saleviter S. Development of graphene quantum dots-based optical sensor for toxic metal ion detection. Sensors. 2019;19:3850-3879. doi: $10.3390 / \mathrm{s} 19183850$

32. Kamaruddin N, Bakar AA, Mobarak N, Zan MS, Arsad N. Binding affinity of a highly sensitive $\mathrm{Au} / \mathrm{Ag} / \mathrm{Au} / \mathrm{Chitosan}$-graphene oxide sensor based on direct detection of $\mathrm{Pb}^{2+}$ and $\mathrm{Hg}^{2+}$ ions. Sensors. 2017;17:2277. doi:10.3390/s17102277

33. Hashim HS, Fen YW, Omar NAS, Abdullah J, Daniyal WMEMM, Saleviter S. Detection of phenol by incorporation of gold modified-enzyme based graphene oxide thin film with surface plasmon resonance technique. Opt Express. 2020;28:9738-9752. doi:10.1364/OE.387027

34. Hossain MB, Rana MM, Abdulrazak LF, Mitra S, Rahman M. Graphene- $\mathrm{MoS}_{2}$ with $\mathrm{TiO}_{2}$ single bond $\mathrm{SiO}_{2}$ layers based surface plasmon resonance biosensor: numerical development for formalin detection. Biochem Biophysics Reports. 2019;18:100639. doi:10. 1016/j.bbrep.2019.100639

35. Barnhart KT, Guo W, Cary MS, et al. Differences in serum human chorionic gonadotropin rise in early pregnancy by race and value at presentation. Obstet Gynecol. 2016;128:504-511.
36. Palacio M, Jauniaux E, Kingdom J, Dell E, Sheldrake A, Rodeck CH. Perinatal outcome in pregnancies with a positive serum screening for Down's syndrome due to elevated levels of free $\beta$-human chorionic gonadotropin. Ultrasound Obstet Gynecol. 1999;13:58-62. doi:10. 1046/j.1469-0705.1999.13010058.x

37. Canfield RE, O'Connor JF, Birken S, Krichevsky A, Wilcox AJ. Development of an assay for a biomarker of pregnancy and early fetal loss. Environ Health Perspect. 1987;74:57-66. doi:10.1289/ ehp. 877457

38. Montagnana M, Trenti T, Aloe R, Cervellin G, Lippi G. Human chorionic gonadotropin in pregnancy diagnostics. Clin Chim Acta. 2011;412:17-18. doi:10.1016/j.cca.2011.05.025

39. Lu Q, Li Y, Shi H, Lang X, Wang Y. The value of ratio of hCG, progesterone in local blood of pregnancy location versus venous blood in the diagnosis of ectopic pregnancy. Int J Clin Exp Med. 2015;8:9477-9483.

40. Letterie GS, Hibbert M. Serial serum human chorionic gonadotropin (hCG) levels in ectopic pregnancy and first trimester miscarriage. Arch Gynecol Obstet. 2000;263:168-169. doi:10.1007/s004040050275

41. Lempiäinen A, Hotakainen K, Blomqvist C, Alfthan H, Stenman UH. Hyperglycosylated human chorionic gonadotropin in serum of testicular cancer patients. Clin Chem. 2012;58:1123-1129.

42. Lenhard M, Tsvilina A, Schumacher L, et al. Human chorionic gonadotropin and its relation to grade, stage and patient survival in ovarian cancer. BMC Cancer. 2012;12:2-8. doi:10.1186/1471-2407-12-2

43. Gronowski AM, Fantz CR, Parvin CA, et al. Use of serum FSH to identify perimenopausal women with pituitary hCG. Clin Chem. 2008;54:652-656. doi:10.1373/clinchem.2007.100305

44. Helmy S, Mavrelos D, Sawyer E, et al. Serum human chorionic gonadotropin $(\beta-h C G)$ clearance curves in women with successfully expectantly managed tubal ectopic pregnancies: a retrospective cohort study. PLoS One. 2015;10:e0130598. doi:10.1371/journal. pone. 0130598

45. Prasad PV, Chaube SK, Shrivastav TG, Kumari GL. Development of colorimetric enzyme-linked immunosorbent assay for human chorionic gonadotropin. J Immunoassay Immunochem. 2006;27:15-30. doi:10.1080/15321810500403649

46. Teixeira S, Ferreira NS, Conlan RS, Guy OJ, Sales MGF. Chitosan/ AuNPs modified graphene electrochemical sensor for label-free human chorionic gonadotropin detection. Electroanalysis. 2014;26:2591-2598. doi:10.1002/elan.201400311

47. Islam K, Suhail A, Pan G. A label-free and ultrasensitive immunosensor for detection of human chorionic gonadotrophin based on graphene FETs. Biosensors. 2017;7:2-10.

48. Wang H, Guo W, Pei M. A novel label-free electrochemical immunosensor based on the composite of LPCs-SnS2 and AuNPs for the detection of human chorionic gonadotropin. New J Chem. 2017;41:11600-11606. doi:10.1039/C7NJ01774J

49. Xia N, Wang X, Liu L. A graphene oxide-based fluorescent method for the detection of human chorionic gonadotropin. Sensors (Basel). 2016;16(10):1699.

50. Chiu NF, Huang TY. Sensitivity and kinetic analysis of graphene oxide-based surface plasmon resonance biosensors. Sens Actuators $B$ Chem. 2014;197:35-42. doi:10.1016/j.snb.2014.02.033

51. Chiu NF, Fan SY, Yang CD, Huang TY. Carboxyl-functionalized graphene oxide composites as SPR biosensors with enhanced sensitivity for immunoaffinity detection. Biosen Bioelectron. 2017;89:370-376. doi:10.1016/j.bios.2016.06.073

52. Chiu NF, Tai MJ, Wu HP, Lin TL, Chen CY. Development of a bioaffinity SPR immunosensor based on functionalized graphene oxide for the detection of pregnancy-associated plasma protein A2 in human plasma. Int J Nanomedicine. 2019;14:6735-67487. doi:10. 2147/IJN.S213653

53. Sun X, Liu Z, Welsher K, et al. Nano-graphene oxide for cellular imaging and drug delivery. Nano Res. 2008;1:203-212. doi:10.1007/ s12274-008-8021-8 
54. Chiu NF, Yang HT. High-sensitivity detection of the lung cancer biomarker CYFRA21-1 in serum samples using a Carboxyl-MoS2 functional film for SPR-based immunosensors. Front Bioeng Biotechnol. 2020;8:234-247. doi:10.3389/fbioe.2020.00234

55. Kang JH, Kim T, Choi J, et al. Hidden second oxidation step of hummers method. Chem Mater. 2016;28:756-764. doi:10.1021/acs. chemmater. $5 \mathrm{~b} 03700$

56. Hong BJ, Compton OC, An Z, Eryzazici I, Nguyen ST. Successful stabilization of graphene oxide in electrolyte solutions: enhancement of bio-functionalization and cellular uptake. ACS Nano. 2012;24:63-73. doi:10.1021/nn202355p

57. Chiu NF, Yang CD. Real-time and stepwise deoxidization processes to tune the photoluminescence properties of graphene oxide using EC-SPR spectroscopy. RSC Adv. 2018;8:11557-11565. doi:10.1039/ C7RA13594G

58. Chiu NF, Chen CC, Yang CD, Kao YS, Wu WR. Enhanced plasmonic biosensors of hybrid gold nanoparticle-graphene oxide-based label-free immunoassay. Nanoscale Res Lett. 2018;13:152. doi:10.1186/s11671-018-2565-7

59. Chiu NF, Yang CD, Chen CC, Kuo CT. Stepwise control of reduction of graphene oxide and quantitative real-time evaluation of residual oxygen content using EC-SPR for a label-free electrochemical immunosensor. Sens Actuators B Chem. 2018;258:981-990. doi:10.1016/j.snb.2017.11.187

60. Tauc J. Electronic properties of amorphous materials: changes are considered which occur when the long-range order typical for crystals disappears. Science. 1967;158:1543-1548. doi:10.1126/science.158. 3808.1543

61. Hsu HC, Shown I, Wei HY, et al. Graphene oxide as a promising photocatalyst for $\mathrm{CO}_{2}$ to methanol conversion. Nanoscale. 2013;5:262-268. doi:10.1039/C2NR31718D

62. Chiu NF, Tu YC, Huang TY. Enhanced sensitivity of anti-symmetrically structured surface plasmon resonance sensors with zinc oxide intermediate layers. Sensors. 2013;14:170-187. doi: $10.3390 / \mathrm{s} 140100170$

63. Rossi C, Homand J, Bauche C, et al. Differential mechanisms for calcium-dependent protein/membrane association as evidenced from SPR-binding studies on supported biomimetic membranes. J Biochemistry. 2003;42:15273-15283. doi:10.1021/bi035336a
64. Omar NAS, Fen YW, Abdullah J, et al. Sensitive detection of dengue virus type 2 E-proteins signals using self-assembled monolayers/reduced graphene oxide-PAMAM dendrimer thin film-SPR optical sensor. Sci Rep. 2020;10:1-15. doi:10.1038/s41598-02059388-3

65. Omar NAS, Fen YW, Saleviter S, et al. Experimental evaluation on surface plasmon resonance sensor performance based on sensitive hyperbranched polymer nanocomposite thin films. Sens Actuators a Phys. 2020;303:111830.

66. Kecili R, Hussain CM. Chapter 4 - mechanism of adsorption on nanomaterials, nanomaterials in chromatography-current trends in chromatographic research technology and techniques. 2018:89-115.

67. Peterlinz KA, Georgiadis R. In situ kinetics of self-assembly by surface plasmon resonance spectroscopy. Langmuir. 1996;12 (20):4731-4740. doi:10.1021/la9508452

68. Lin S, Lee AS-Y, Lin -C-C, Lee C-K. Determination of binding constant and stoichiometry for antibody-antigen interaction with surface plasmon resonance. Curr Proteomics. 2006;3:271-282. doi:10.2174/157016406780655586

69. Xia N, Chen Z, Liu Y, Ren H, Liu L. Peptide aptamer-based biosensor for the detection of human chorionic gonadotropin by converting silver nanoparticles-based colorimetric assay into sensitive electrochemical analysis. Sens Actuators B Chem. 2017;243:784-791. doi:10.1016/j.snb.2016.12.066

70. Cole LA, Shahabi S, Oz UA, Bahado-Singh RO, Mahoney MJ. Hyperglycosylated human chorionic gonadotropin (invasive trophoblast antigen) immunoassay: a new basis for gestational Down syndrome screening. Clin Chem. 1999;45:2109-2119. doi:10.1093/ clinchem/45.12.2109

71. Shiefa S, Amargandhi M, Bhupendra J, Moulali S, Kristine T. First trimester maternal serum screening using biochemical markers PAPP$\mathrm{A}$ and free $\beta$-hCG for Down syndrome, patau syndrome and edward syndrome. Indian J Clin Biochem. 2013;28:3-12. doi:10.1007/ s12291-012-0269-9
International Journal of Nanomedicine

\section{Publish your work in this journal}

The International Journal of Nanomedicine is an international, peerreviewed journal focusing on the application of nanotechnology in diagnostics, therapeutics, and drug delivery systems throughout the biomedical field. This journal is indexed on PubMed Central, MedLine, CAS, SciSearch ${ }^{\mathbb{R}}$, Current Contents ${ }^{\mathbb{B}} /$ Clinical Medicine,
Journal Citation Reports/Science Edition, EMBase, Scopus and the Elsevier Bibliographic databases. The manuscript management system is completely online and includes a very quick and fair peer-review system, which is all easy to use. Visit http://www.dovepress.com/ testimonials.php to read real quotes from published authors. 